\title{
Rare birds in Nepal
}

\section{Carol Inskipp $^{1^{*}}$ (D) | Hem Sagar Baral ${ }^{2,3}$ (D) Sanjib Acharya ${ }^{4}$ (D) Hathan Chaudhary ${ }^{5}$ | Manshanta Ghimire $^{6}$ (D) Dinesh Giri ${ }^{7}$}

${ }^{1} 3$ High Street, Stanhope, Bishop Auckland, Co. Durham DL132UP, UK

${ }^{2}$ Zoological Society of London Nepal Office, PO Box 5867, Kathmandu Nepal

${ }^{3}$ School of Environmental Sciences, Charles Sturt University, Albury-Wodonga, Australia

${ }^{4}$ Koshi Bird Society, Prakashpur, Barahachhetra Municipality, Sunsari, Nepal

${ }^{5}$ Nepalese Ornithological Union, PO Box 10918, Kathmandu, Nepal

${ }^{6}$ Pokhara Bird Society, PO Box 163, Pokhara, Nepal

${ }^{7}$ Bird Education Society, Chitwan, Nepal

*Correspondence: carol.inskipp@btinternet.com

Received: 06 December 2020 | Revised: 16 December 2020 | Accepted: 16 December 2020

\begin{abstract}
This paper aimed to fulfil the knowledge gap on the status of vagrants and rare birds of Nepal. Records of all Nepal's bird species that were previously considered vagrants by the National Red List of Nepal's Birds (2016) were collated and detailed with localities, dates and observers. Species recorded since 2016, including vagrant species, were also covered. A total of 92 species was assessed to determine if they were vagrants, that is species that had a total of 10 or less records. It was concluded that six species are no longer vagrant and we recommend these for national red list assessment. Nepal currently has a total of 71 vagrant species. In addition, four vagrant species have still to be accepted by the Nepal Rare Birds Committee before they can be officially included on the Nepal bird list. Nine species have so far only been recorded in the $19^{\text {th }}$ century. Red-faced liocichla Liocichla phoenicea, was previously one of these, but was re-found In Nepal after the National Red List was published in 2016; it is a very rare and very local resident. Himalayan grasshopper-warbler Locustella kashmirensis is a recent split and now considered a full species (instead of a subspecies); it is probably an altitudinal migrant in Nepal. Despite great advances in our ornithological knowledge of Nepal, there is still high potential to find new species, especially of passerine birds and in the less explored parts of the country.
\end{abstract}

Keywords: Bird, Nepal, Rare species, Status assessment, Vagrant

\section{1 | Introduction}

The National Red List of Nepal's Birds (Inskipp et al. 2016, Inskipp et al. 2017) made a comprehensive assessment of Nepal's birds and was the fourth systematic assessment on the status of Nepal's birds. Unlike previous assessments where only the threatened species were reviewed, the 2016 study covered the status and threats to all the country's bird species that qualified for red list assessment in order to prioritize and catalyse action for bird conservation in Nepal. It was a collaborative project between the Department of National Parks and Wildlife Conservation, Ministry of Forests and Environment, Government of Nepal, Himalayan Nature, National Trust for Nature Conservation and the Zoological Society of London. A number of other bird conservation organisations and Nepal's ornithologists, bird researchers, nature guides, and birdwatchers also contributed to the project. The species accounts are available for free download in an easily searchable database at Himalayan Nature (2020a). However, vagrants, that is species recorded 10 times or less, and species only recorded in the $19^{\text {th }}$ century were excluded from the Red List assessment. This presented a difficult situation for budding ornithologists and bird enthusiasts for a reliable reference to the status of rarer species.

In this paper, we aim to fulfil the knowledge gap on the status of vagrants and rare birds of Nepal. We present our assessment of all of Nepal's vagrant species including those that were recorded after the Red List was published. We also recommend the changed status of species which were previously considered vagrants but are now considered rare visitors or rare residents. 


\section{2 | Materials and methods}

All known records of species that were previously considered vagrants were compiled with details of locality, date and observers. A comprehensive search was undertaken for new records of rarely observed species. Online sources including ebird and Facebook were researched. Over 2,400 published papers and journals, and unpublished records were researched including 2,315 references detailed in the Nepal bird bibliography (Inskipp 2012). Over 60 birdwatchers and ornithologists were consulted.

In total, the occurrence and status of 92 species in Nepal was reviewed. The number of records of each species was counted, while ensuring as far as possible that there were no duplicates of individual birds. A species was considered a vagrant if there were 10 records or less, that is species sightings in 10 different localities/timings. In some cases, the number of actual records was more than 10 , but the species were still considered to be vagrant because there were a number of records of the same individual(s) e.g. bean goose Anser fabalis. Where there were more than 10 records for a species, its status was assessed.

\section{3 | Results}

Of the 92 species that were assessed, six species had more than 10 records in the country meriting national red list assessment. These are: fulvous whistling-duck Dendrocygna bicolor, Chinese spot-billed duck Anas zonorhynchna, slaty-breasted rail Lewinia striatus, white-tailed lapwing Vanellus leucurus, whimbrel Numenius phaeopus and Indian vulture Gyps indicus. Records of four species (green imperial pigeon Ducula aenea, black-breasted thrush Turdus dissimilis, common reed bunting Schoeniclus schoeniclus and striolated bunting Emberiza striolata) need to be reviewed and accepted by the Nepal Rare Birds Committee before they can be officially included on the Nepal bird list. Nine species were only recorded in the $19^{\text {th }}$ century. Red-faced liocichla Liocichla phoenicea was previously one of these but was re-found in Nepal after the National Red List was published in 2016. Himalayan grasshopper-warbler Locustella kashmirensis is a recent split and is now considered a full species (instead of a subspecies). Therefore, there are currently 71 accepted vagrant species in Nepal. Summary details of all the 92 species that were reviewed are provided below.
The results indicate that the majority of rare bird records from Nepal have been of non-passerine birds, while there is a smaller number of records of passerines, especially the more elusive species. The species accounts also show that many of the records are from the better-known protected areas and other parts of the country which have been well studied ornithologically. There still remain large areas of Nepal which are little explored for birds, especially in the high mountains.

\section{Rain quail Coturnix coromandelica}

First recorded by Brian $\mathrm{H}$. Hodgson who obtained at least six specimens from the Kathmandu Valley in April, May and August in the $19^{\text {th }}$ century (year unknown) including a female in breeding condition (Hodgson 1829a, 1837a). Only two other records, both from the Valley. One specimen was collected by Robert $L$. Fleming Sr. at Bhaktapur on 25 July 1956 (Fleming \& Traylor 1961). Another specimen was collected by G. B. Gurung near New Road, Kathmandu on 11 April 1959 (Krabbe 1983).

\section{Jungle bush-quail Perdicula asiatica}

Only recorded by Brian $\mathrm{H}$. Hodgson who found it chiefly in the sub-Himalayan valleys in the $19^{\text {th }}$ century (year unknown) (Gray \& Gray 1846). Also considered by Hodgson as migrant (Hodgson 1837a).

\section{Fulvous whistling-duck Dendrocygna bicolor}

There are over 10 records of this species so it can no longer be considered a vagrant. It is a winter visitor, regular at Barju Lake, Sunsari district and very uncommon elsewhere. First recorded by Frank Lambert et al. who saw one bird with a flock of about 1500 lesser whistling duck D. javanica on 12 February 1979 (Lambert 1979, Redman \& Murphy 1979, Redman et al. 1984). One bird was seen in ponds near Kusaha, Koshi Tappu Wildlife Reserve on 14 January 2000 and later seen amongst 700 lesser whistling duck D. javanica at Koshi Barrage from 16 February 2000 for about a week by Dinesh Giri, Tika Ram Giri, Suchit Basnet, Som GC and Badri Chaudhary (Giri \& Choudhary 2000a). There were two records from Lumbini, Rupendehi district: four birds seen on the south side of the museum on 15 January 2011 by Henry Stirrett (ebird) and two seen to the west of the Mayadevi Temple on 16 February 2017 (Som GC Pers. Comm., November 27, 2020). 
There were a few records from Jagdishpur Reservoir, Kapilvastu district: three birds on 24 February 2018 (Som GC Pers. Comm., November 27, 2020); one bird in January 2019 (Dinesh Giri Pers. Comm., December 3, 2020); one bird between October 2019 and March 2020 (Bhusal et al. 2020), and two birds in January 2020 (Prashant Ghimire, Facebook). There were several records from Barju Lake, Sunsari district: 16 birds on 10 January 2019 by Sanjib Acharya and Koshi Bird Society team (ebird) and 14 birds on 17 February 2019 (Sanjib Acharya, Hem Sagar Baral, Tika Ram Giri and Carol Inskipp (ebird) which were possibly some of the same individuals. Six birds were seen on 27 December 2019 by Ramesh Chaudhary, Johan Petersson and Stina Nilson (Tek Bahadur Gurung Pers. Comm., December 7, 2020). A flock of 16 birds was recorded after one year on 13 January 2020 (Sanjib Acharya, Suman Acharya, Dinesh Ghimire and Koshi Bird Society team (ebird) and was possibly the same birds as recorded on 10 January 2019. A total of 60 birds was seen there in February and early March 2020 (Suchit Basnet Pers. Comm., November 20, 2020) and at least eight birds on 26 November 2020 by Sanjib Acharya (ebird).

\section{Whooper swan Cygnus cygnus}

Only recorded by Brian Hodgson who obtained a specimen in January 1829 from the Kathmandu Valley (Hodgson 1829a, 1833a).

\section{Tundra swan Cygnus columbianus}

The only record is of one bird seen on 23 February 1978 on the Narayani River at Chitwan by John Gooders (Gooders 1978).

\section{Bean goose Anser fabalis}

The first record was of one seen with ruddy shelduck Tadorna ferruginea by the Rapti River, Sauraha, Chitwan National Park buffer zone on 28 November 1985 by Kaj Halberg (Halberg 1987). Later it was seen there on 3 and 7 December 1985 by Peter Sieurin (Sieurin 1987) and on 12 December 1985 by Robert Roberts (Roberts 1985). Another individual was seen on the Narayani River near Island Jungle Lodge, near Chitwan National Park with bar-headed geese $A$. indicus on 31 December 1992 by the naturalists at Island Jungle Lodge (Lama 1992).

One bird was observed on marshes by the Dhungre River, Chitwan National Park with a small flock of bar-headed geese and two Ruddy Shelduck on 15 February 2004. It was first identified by $\mathrm{S}$. Mahato, aided by $\mathrm{D}$. Timilsina and was later seen by a number of Bird Education Society members on the same day, as well as other observers on 16 February. One bird was also seen on 25 and 26 February at the same site by several Bird Education Society members, including Hem Subedi who photographed it (Giri \& Choudhary 2004a, Inskipp 2005). One was observed in the Narayani river in December 2010 by Hem Sagar Baral, Dev Narayan Chaudhary and lain Taylor (Hem Sagar Baral Pers. Obs.). Two birds were seen with three greater white-fronted geese $A$. albifrons on the Rapti River in front of Dobhan Community Forest, Chitwan National Park on 4 February 2016, by Utsab Jung Thapa, Hemanta Darai, Tek Bahadur Gurung, Basu Bidari, Badri Chaudhary, Hathan Chaudhary and other Bird Education Society members (Tek Bahadur Gurung Pers. Comm., December 7, 2020).

Three birds were seen on the Rapti River at Jindaganighat Kumroj, eastern part of Chitwan National Park buffer zone on 21 January 2017 (Basu Bidari Pers. Comm., December 7, 2020). One bird was seen on Phewa Lake by Anil Gurung, Mikael Hakke and M. Jayaram on 23 January 2017 (Tek Bahadur Gurung Pers. Comm., December 7, 2020). One bird was seen on 17 January 2017 on Jagadishpur Reservoir during the annual midwinter waterbird count by Dheeraj Chaudhary, Mandip Dahal and Dinesh Giri (Dinesh Giri Pers. Comm., December 7, 2020). One was also observed there with a bar-headed goose Anser indicus and a greylag goose Anser anser in February 2017 during the Friends of Nature Owl Festival (Hem Sagar Baral, Dinesh Giri, Carol Inskipp and many observers) (Dinesh Giri Pers. Comm., December 7, 2020). One was photographed near Koshi Bird Observatory on 21 November 2020 (Sanjib Acharya Pers. Comm., November 21, 2020).

\section{Greater white-fronted goose Anser albifrons}

The first record was an individual seen on 24 March $20041 \mathrm{~km}$ west of Hawa Mahal in Koshi Tappu Wildlife Reserve with two bar-headed geese $A$. indicus and two ruddy shelducks Tadorna ferruginea by Som GC, Paul Sutherland and Anil Timsina (Giri \& Choudhary 2004b, GC 2005). Three birds were photographed in the reserve on 16 April 2017 by Dinesh Ghimire (ebird) and three birds were seen near Kusaha in the reserve on 16 December 2017 by Dinesh Ghimire and Koshi Bird Society team (ebird).

Four birds were recorded in the Phewa wetlands from midDecember 2017 to the first week of February 2018 by Manshanta Ghimire and Pokhara Bird Society team (Manshanta Ghimire Pers. Comm., December 7, 2020). Presumably the same birds 
were seen there on 27 December 2017 by Mike Greenfelder (ebird) and photographed on 28 December 2017 by Pratap Gurung (ebird) and Pokhara Bird Society team (Manshanta Ghimire Pers. Comm., December 7, 2020). At the same site, one bird was photographed on 27 January 2018 by Rajendra Gurung (ebird) and four birds were photographed there on 28 January 2018 (Tek Gharti Magar, Facebook); also, four birds were seen there on 10 March 2018 by Neils Bomholt (ebird).

There were several records from Chitwan National Park and buffer zone. Three birds were seen with two bean geese $A$. fabalis on the Rapti River in front of Dobhan Comnmunity Forest on 4 February 2016 by Utsab Jung Thapa, Hemanta Darai, Tek Bahadur Gurung, Basu Bidari, Badri Chaudhary, Hathan Chaudhary and other Bird Education Society members (Tek Bahadur Gurung Pers. Comm., December 7, 2020). One bird was photographed at Meghauli in the buffer zone on 17 January 2017 by Nikita Khamparia (ebird). Three birds were seen at Jindagani Ghat in the buffer zone on 7 January 2018 by Tek Bahadur Gurung and other Bird Education Society members (Tek Bahadur Gurung Pers. Comm., December 7, 2020). Two birds were photographed in the national park on 28 January 2018 by Utsab Jung Thapa (Facebook). Three birds were seen at Amaltari Ghat in the national park on 17 November 2020 by Nischal Adhikari (Tek Bahadur Gurung Pers. Comm., December 7, 2020) and lan Hearn (ebird).

\section{Long-tailed duck Clangula hyemalis}

An immature male was seen by Tim and Carol Inskipp from 13 to 15 March 1981 at Koshi Barrage (Inskipp \& Inskipp 1981). A pair was also seen at the Barrage in February and March 1982 by Craig Robson (Robson 1982); Mick Turton and Graham Speight (Turton \& Speight 1982) and S. Whitehouse (Whitehouse 1982).

A female in winter plumage was seen on 17 and 18 February 1997 in Koshi Tappu Wildlife Reserve by Hathan Choudhary, Tika Ram Giri, Suchit Basnet, Ramesh Karki and Martin Pitt (ebird); also seen there on 21 February 1997 by C. S. Gurung. One bird was observed on the Koshi River, near Kosi Bird Observatory in 2011 (Badri Chaudhary Pers. Comm., to Hem Sagar Baral, 2011). One bird was recorded on Jagdishpur Reservoir, Kapilvastu district, on 3 March 1997 by Suresh Sakya (Giri \& Choudhary 1997).

\section{Smew Mergellus albellus}

First recorded by Frank M. Bailey who collected a specimen at Bilauri, Kanchanpur district at about 160 m on 22 January 1937 (Bailey 1938). There were several records from Koshi. One bird was seen on 15 and 16 January 1981 at Koshi Barrage by Jim Hall (Hall 1981). There were several sightings of a female or immature from10 January to 11 February 1997 on a small pond near Titrigachhi guard post in Koshi Tappu Wildlife Reserve by Paul Holt, Tika Ram Giri, Hathan Choudhary, Suchit Basnet, Badri Chaudhary, Ramesh Karki and Shankar Tiwari (Giri \& Choudhary 1997). A male was seen to the west of Titrigachhi on the Koshi River on 29 January 2002 by Dinesh Giri, Som G. C, Badri Chaudhary, Dhakaram Giri and Gangaram Singh and on the Koshi River west of Kusaha on 28 February 2002 by Som GC and Dinesh Giri (Som GC Pers. Comm., November 27, 2020). There were two records from Chitwan National Park: one on 1 February 1983 by Jonathon Ross (Gurung 1983, Ross 1983) and a female or immature on 5 January 1999 on the Charhara, Rapti River by Bishnu Mahato and Hathan Choudhary (Giri et al. 1999). One bird was observed in February 2012 on Phewa Lake by Ramesh Chaudhary and Tika Ram Giri. One was seen while rafting on the Karnali River on 19 March 2019 (Som GC Pers. Comm., November 27, 2020).

\section{Red-breasted merganser Mergus serrator}

The first record was of a first winter male at Koshi Barrage on 24 and 25 February 1987 seen by Vernon Eve and Gary Hibberd. (Eve \& Hibberd 1987). Two females or immatures were seen at the Barrage on 9 February 1989 by Peter Kennerley and Mike Turnbull (Kennerley \& Turnbull 1989, ebird). A female was seen at the Barrage on 28 January 1992 by J. Andersson and Krys Kazmierczak (Lama 1995).

One adult female was recorded on 5 April 2008 on Phewa Lake, near Fishtail Lodge, Pokhara by Paul Triggs, Hari K. C. and Som GC (Basnet 2008, Giri \& Choudhary 2008).

\section{Greater scaup Aythya marila}

First recorded by Tim Andrews who recorded one bird on Phewa Lake on 8 February 1985 (Andrews 1986). A pair was seen on 9 February 1989 at Koshi Barrage (Kennerley \& Turnbull 1989, ebird). 
There were a few records of single birds from Jagadishpur Reservoir, Kapilvastu district: on 19 January 2016 by Badri Chaudhary and Hem Sagar Baral (Hem Sagar Baral Pers Obs. 2016) and on 16 February 2019 (Som GC Pers. Comm., November 27, 2020). One bird photographed on 2 January 2020 by Johan Peterson, Ramesh Chaudhary and Stina Nilson (Anonymous 2020), and recorded between October 2019 and March 2020 by Bhusal et al. (2020) was probably the same individual. Single birds were seen in Phewa wetlands in December 2017, November 2018 and February and April 2019 by Manshanta Ghimire and Pokhara Bird Society team (Manshanta Ghimire Pers. Comm., December 3, 2020 and Facebook).

\section{Pink-headed duck Rhodonessa caryophyllacea}

Only recorded by Brian $\mathrm{H}$. Hodgson who collected a specimen from the Kathmandu Valley on 15 September (year unknown) in the $19^{\text {th }}$ century (Hodgson 1829a, 1844).

\section{Mandarin duck Aix galericulata}

The first record was of a male photographed by Sharifin Gardiner on the lower Arun River $1 \mathrm{~km}$ below Kattike Ghat on 21 January 1990 (Gardiner 1991). A female was seen at Chitwan on 4-5 January 2000 by M. Sutton, John Gregory and Mike Edgecombe (Giri \& Choudhary 2000b). Single birds were seen on Lami Tal, Chitwan National Park on 14 February 2014 by Basu Bidari) and on the Rapti River on 17 February 2014 by Suk Ram Mahato (Basu Bidari Pers. Comm., December 7, 2020).

One sub-adult male was seen and photographed at Amaltari on the Narayani River, Chitwan National Park on 23 December 2019 by Dhan Bahadur Chaudhary, Gyan Bahadur Rai, Pradyot Rana and Dhan Bahadur Tamang (Anonymous 2019). A subadult male was seen at Nawalparasi by Raju Tamang, Chudamani Chaudhary, Fuleswor Chaudhary, Pratap Gurung and Deepak Chaudhary on 25 and 26 December 2019 (Tek Bahadur Gurung Pers. Comm., December 7, 2020) and photographed there on 28 December 2019 by Khagendra Mahato (ebird).

On Barju Lake, Sunsari district an adult male was seen on 28 December 2019 by Bird Education Society members: Ram Krishna Mahato, Bishnu Mahato, Chungba Sherpa, Pemba Sherpa, Khagendra Mahato and Dhan Bahadur Chaudhary (Tek Bahadur Gurung Pers. Comm., December 7, 2020). One was photographed there on 29 December 2019 by Nabin Regmi and Sewant Nirauli (Anonymous 2019) and also seen there on 13
January 2020 by Sanjib Acharya and Koshi Bird Society team (ebird), in February 2020 (Suchit Basnet) and on 14 March 2020 (Tek Bahadur Gurung Pers. Comm., December 7, 2020).

One was observed on 6 January 2020 on the Marsyangdi River at Abu Khareni, where there is a hydro dam (Vimal Thapa Facebook.).

\section{Chinese spot-billed duck Anas zonorhyncha}

There were more than 10 records of this species so it can no longer be considered a vagrant. It is probably a very uncommon winter visitor and passage migrant.

The first record was of one seen during a Koshi River boat ride on 27 February 2002 by Dinesh Giri and Gangaram Singh (Dinesh Giri Pers. Comm., December 3, 2020). Two birds were photographed by Sanjib Acharya and Ole Goldschimidt on the Koshi River, near Kosi Bird Observatory on 6 March 2015 (ebird). One bird was photographed on the Ghodaghodi lake complex in February 2017 by Manshanta Ghimire, Pratap Gurung and Tek Bahadur Gharti Magar) (Manshanta Ghimire Pers. Comm., December 3, 2020). One was recorded from Badhaiya Lake, Bardia district on 15 December 2019 by Dinesh Giri, Som GC, Raju Thapa, and Dharma Giri (Dinesh Giri Pers. Comm., December 3, 2020).

One was photographed on Taudaha Lake, Kathmandu Valley by Umang Jung Thapa on 3 March 2019 (Facebook). There were three records of single birds from Jagdishpur reservoir, Kapilvastu district: on 7 February 2016 by Dinesh Giri, Som GC, Clyde O'Donnell, and Manoj Paudel (Dinesh Giri Pers. Comm., December 3, 2020); a male on 12 March 2018 by Som GC, Dinesh Giri and Seelush Chhetri (Dinesh Giri Pers. Comm., December 3, 2020), and between October 2019 and March 2020 (Bhusal et al. 2020).

There were several records from Barju Lake, Sunsari district. Eight birds were seen on 10 January 2019 by Sanjib Acharya and Koshi Bird Society team (ebird); three birds on 17 February 2019 by Sanjib Acharya, Hem Sagar Baral, Tika Ram Giri, Carol Inskipp and Koshi Bird Society team (ebird), and six birds on 13 January 2020 by Suman Acharya, Dinesh Ghimire, Sanjib Acharya and Koshi Bird Society team (ebird).

\section{Baikal teal Sibrionetta formosa}

First recorded by Steen Christensen, Rob Bijlsma, Frank de Order, and M. Henriksen who found two birds resting by the Kali Gandaki River near Larjung, Annapurna Conservation Area at 
about $2560 \mathrm{~m}$ on 16 October 1984 (Chritensen et al. 1984). Single adult males were seen at Koshi Barrage on 23 February 1987 by Vernon Eve and Gary Hibberd (Eve \& Hibberd 1987) and on 9 February 1989 (Kennerley \& Turnbull 1989, ebird). One adult male was observed at Taudaha, Kathmandu Valley on 8 May 2005 by Arend van Riessen (ebird) and later seen there by Mark Mallalieu, Hem Sagar Baral and Dev Ghimire (Inskipp 2006).

The latest record was of one recorded on Barju lake in March 2012 by Suchit Basnet and Anish Timsina (Suchit Basnet Pers. Comm., November 20, 2020).

\section{Greater flamingo Phoenicopterus roseus}

First recorded by Brian $\mathrm{H}$. Hodgson as a transient visitor to the Kathmandu Valley in the $19^{\text {th }}$ century (years unknown) (Hodgson1833a), although no specimen records can be traced.

A small group was seen at Koshi Barrage in winter 1973 by J. W. Propst (Fleming Sr. et al. 1979). An immature was also observed at Koshi Barrage by Malcolm Ausden and Siobhan Mellon on 10 and 11 May 1992 (Anonymous 1992b).

One bird sighted on 3 February 2010 by the Rapti River, Chitwan National Park was the first record for the park; seen by Bishnu Lama, Hem Subedi, Basu Bidari, Ramgir Mahato, Tika Ram Giri, Bishnu Mahato, Anil Gurung and Hem Sagar Baral (Giri \& Choudhary 2010a). This bird was last seen there on 14 February 2010 by Bishnu Lama and Hem Subedi.

\section{[Green imperial pigeon Ducula aenea}

One bird photographed by Devendra Kharel at Mechinagar-7, Jhapa district on 24 November will be a new species for Nepal, if accepted by the Nepal Rare Birds Committee.]

\section{Sykes's nightjar Caprimulgus mahrattensis}

The only record is of one bird seen about $3 \mathrm{~km}$ south of Koshi Barrage on 1 January 2008 by Badri Chaudhary, Anish Timilsina and Barry McCarthy (Basnet 2008).

\section{Slaty-breasted rail Lewinia striatus}

There are more than 10 records of this species so it can no longer be considered a vagrant. It is probably a very uncommon visitor and probably also a rare resident.

The first record is one collected on 16 February 1938 in the eastern Terai at Haraincha, Morang district by F. M. Bailey (Bailey 1938). One bird was seen on a small wetland by a temple in Nepalganj on 10 March 1992 (Baral 1992).
Single birds were seen in Chitwan National Park on 27 May 1985 (Hurrell 1988) and on 6 March 1987 (Juliusberger 1987). Also recorded at Chitwan (number unknown) from 27 January to 2 February 1993 by Alan Lewis and Richard Rowland (Lama 1995). One bird was located at Lami Tal on 18 February 2008 by Babu Ram Regmi, Paul Willoughby and Bishnu Mahato (Giri \& Choudhary 2008). One bird was photographed in November 2016 in wet farmland, Chitwan district, outside Chitwan National Park and buffer zone (Dinesh Giri Pers. Comm., December 3, 2020); one was seen at Sauraha, Chitwan National Park buffer zone on 24 November 2017 by David Lane (ebird), and one was seen at Temple Tiger Ghol, Chitwan National Park on 3 June 2020 (Dhan Bahadur Chaudhary Pers. Comm., November 20, 2020).

There were a few records from Kosi Bird Observatory: one bird on 20 July 2011 by Sanjib Acharya (ebird); one bird on 22 July 2012 by Dinesh Ghimire (ebird), and two birds on 25 August 2012 by Sanjib Acharya and Koshi Bird Society team (ebird). One was observed at Prakashpur village, Koshi on 7 July 2015 by Sanjib Acharya (ebird).

\section{Western water rail Rallus aquaticus/Eastern water rail $\boldsymbol{R}$.} indicus

First recorded by Brian $\mathrm{H}$. Hodgson in the $19^{\text {th }}$ century in October (year unknown) from the Kathmandu Valley (Hodgson 1829a, Sharpe 1894). Also recorded in the Valley in October 1973 when one bird was found dead at Tribhuvan University (Fleming Sr. et al. 1979).

One bird was collected (collector unknown) at Chatra, Sunsari district in November 1958 (Field Museum Chicago collection). There were a number of records from Koshi Barrage and Koshi Tappu Wildlife Reserve. Chiefly single birds have been recorded there irregularly, e.g. in March 1991 (Baral 1991), February 1998 (Prince 1998), March 2004 (Kennerley \& Karki 2004), February 2005 (GC 2010), and February 2009 (Badri Chaudhary verbally 2010), although at least three birds were seen there in February 1993 (Lama 1993c).

\section{Western water rail Rallus aquaticus}

The first record was by Frank Bailey who collected a specimen from Bilauri, Kanchanpur district in January 1937 (Bailey 1938). One seen at Beeshazari Lake, Chitwan National Park buffer zone on 29 January 2011 by Tom Wheatley (ebird). 


\section{Eastern water rail Rallus indicus}

The first record was by Frank M. Bailey who collected a specimen from Bilauri, Kanchanpur district in January 1937 and also at Haraincha, Morang district in February 1938 (Bailey 1938).

There were four records from Koshi Tappu Wildlife Reserve: one bird on 27 March 1997 by Keith Cowton (ebird), two birds on 23 January 1998 by Dominic Mitchell (ebird), one bird at Kusaha near the reserve headquarters on 21 January 2003 (Dinesh Giri Pers. Comm., December 3, 2020), and one bird in the reserve on 22 February 2015 by Sanjib Acharya (ebird).

There were a few records from Chitwan National Park. One bird was observed feeding in Jayamangla Ghol on 15 December 2002 by Dinesh Giri, Som GC and Arjun Chaudhary (Dinesh Giri Pers. Comm., December 3, 2020). One bird was photographed on 9 February 2020 by Raju Tamang (Tek Bahadur Gurung Pers. Comm., December 7, 2020) and also seen on15 February 2020 by Chungba Sherpa, Pemba Sherpa, Som Tamang and other Bird Education Society members (Anonymous 2020).

\section{Spotted crake Porzana porzana}

The only record is one bird seen by Rosemary Cooper near Kusaha, Koshi Tappu Wildlife Reserve on 28 February and 3 March 1990 (Cooper 1991)

\section{Red-throated Ioon Gavia stellata}

An adult in winter plumage was seen at Koshi Barrage from 12 19 February 2002 by Steve Arlow, Dinesh Giri, K. Avanzini, Suchit Basnet, Hathan Choudhary, E. Hoerl, L. Hoerl, R. Kautz, W. Kautz, Aaron Ofner, H. Pfeifhofer, F. Samwald, H. Schiechl, R. Suwal, Graham Tebb and U. Titz (Giri \& Choudhary 2002, Inskipp 2004, Tebb et al. 2004). This is the only record for Nepal.

\section{White stork Ciconia ciconia}

First recorded near Chitwan in winter by P. Alden (Fleming et al 1979). Single birds were seen at Jagdishpur Reservoir, Kapilvastu district on 5 March 1978 by Jack Cox Jr. (Cox 1978); east of Pokhara, Kaski district on 20 February 1986 by Per Alind (Alind 1986), and in Chitwan National Park on 15 February 1989 by S. A. Linderstrom (Linderstrom 1989).

\section{Glossy ibis Plegadis falcinellis}

First recorded by Brian $\mathrm{H}$. Hodgson who obtained a specimen from the Kathmandu Valley on 12 September in the $19^{\text {th }}$ century (year unknown). He described it as a migrant through the Valley remaining in the hills for a few days (Hodgson 1829a, 1844)

Single birds were seen at Koshi Barrage on 14 April 1981 by David Mills and Nick Preston (Mills \& Preston 1981) and on 7 December 2009 by Tika Ram Giri, Badri Chaudhary and Nick Bray (Giri \& Choudhary 2010a). Two birds were recorded at Koshi Tappu Wildlife Reserve on 20 April 1987 by Joel Heinen (Heinen1988) and one was seen there on 25 January 2015 by Sanjib Acharya (ebird)

Three birds were found in Chitwan National Park on 3 March 1988 by John B. Good and John Ryan (Good \& Ryan 1988). One bird was seen by the Dhanudhara Khola, Rapti River on 3 May 2013 by Hemanta and also on 5 May 2013 by Bahsu Bidari and Bird Education Society team (Basu Bidari Facebook). A flock of18 birds was recorded from the Shikari Tal marshes in Shuklaphanta National Park by Devraj Joshi on 18 May 2018 (Joshi 2018 in Poudyal \& Chaudhary 2019)

\section{White-bellied heron Ardea insignis}

Only recorded by Brian $\mathrm{H}$. Hodgson who obtained at least two specimens on 5 April and 10 November in the $19^{\text {th }}$ century (year unknown) from the lower hills including one from Hetauda, Makwanpur district (Hodgson 1829a, 1844).

\section{Great white pelican Pelecanus onocratalus}

The first record was of a pair flying over the Kathmandu Valley seen by J. V. Coapman in 1971 (Fleming Sr. et al. 1979)

Mainly recorded in the Koshi area. Described as an uncommon visitor to Koshi Barrage in the species' non-breeding season between May and December (Gregory-Smith \& Batson 1976). There were other records from Koshi Barrage: in March 1988 (Hurrell 1988) and a flock of 52 on 14 and 15 February 1981 (Baker 1981, Mills \& Preston 1981, Porter et al. 1981). Single birds were observed near Koshi Camp in Koshi Tappu Wildlife Reserve on 31 May 1993 by Hathan Choudhary (Lama 1993b) and near Prakashpur, Koshi Tappu, on 26 June 1993 by Hathan Choudhary (Lama 1994a).

One bird was sighted in Koshi Tappu Wildlife Reserve on 20 January 1994 by Tika Ram Giri, Hathan Choudhary, Guy Thompson, Duncan Orr-Ewing, and Colin Crooke (Lama 1994c). One bird was seen resting on a sand bar near Titrigachhi in the reserve on 28 December 1995 by Hathan Choudhary, Badri Chaudhary, and John Parish (Choudhary 1995/1996). Three birds were observed at Kumal Tal, Beeshajari lake, Chitwan National 
Park buffer zone: on 20 March 2017 by Basu Bidari, Tika Giri, Tek Bahadur Gurung and other Bird Education Society members (Tek Bahadur Gurung Pers. Comm., December 7, 2020); on 20 April 2017 by Khagendra Mahato (ebird) and on 16 May 2017 by Suk Ram Mahato and Ramesh Chaudhary (Tek Bahadur Gurung Pers. Comm., December 7, 2020).

Three birds were seen at Gaidahawa Tal, Rupandehi district on 30 April 2018 by Dharma Giri and Tek Bahadur Gurung (Tek Bahadur Gurung Pers. Comm., December 7, 2020) and one bird on 19 July 2018 by Venerable Metteyya Sakyaputta (Facebook).

\section{Indian cormorant Phalacrocorax fuscicollis}

The only record is of one first seen in Koshi Tappu Wildlife Reserve on 19 March 2009 by Suchit Basnet and Badri Chaudhary (Giri \& Choudhary 2010), and later photographed on 26 March 2009 in the same area by Hannah Philips (ebird).

\section{Eurasian oystercatcher Haematopus ostralegus}

First recorded by Brian $\mathrm{H}$. Hodgson who found it was 'a passage migrant in the hills' in the $19^{\text {th }}$ century (year unknown). He obtained at least one specimen from the Kathmandu Valley on 8 October (Hodgson 1844). The only other record is one seen from 11-14 August 2003 by the Buddhi Rapti River, Baghmara buffer zone community forest, Chitwan National Park buffer zone by Hem Subedi, Kapil Pokharel, R. Mahato, H. Tamang and M. K. Choudhary. It was seen feeding on the river mudflats at times with northern lapwing Vanellus vanellus and also with flocks of Asian pied starling Sturna contra (Giri \& Choudhary 2003b).

\section{Grey plover Pluvialis squatarola}

First recorded by Brian $\mathrm{H}$. Hodgson from the Kathmandu Valley on 2 January and 2 October (years unknown) (Hodgson 1829a, 1844). There were several records from Chitwan National Park. One bird was seen by the Rapti River in November 1979 by Kai Curry-Lindahl (Curry-Lindahl 1979). One bird seen from December 1988 to February 1989 by Hem Sagar Baral (Baral 1989) and also seen in the park in February 1989 by Chris Eastwood, (ebird) possibly refer to the same bird. One bird was seen on the Dhungre River bank, near the National Trust for Nature Conservation Trust centre on 6 September 1997 (Som GC, Govinda Adhikari and Dhaka Ram Giri (Som GC Pers. Comm., November 27, 2020); one bird was seen in old Padampur, Jayamangla on 23 August 1997 by Basu Bidari, Ramesh Chaudhary and other BES members (Basu Bidari Pers.
Comm., December 7, 2020) and one bird was seen there on 12 September 1997 by Dinesh Giri and Som GC (Dinesh Giri Pers. Comm., December 7, 2020). These last three records possibly refer to the same bird (Dinesh Giri Pers. Comm., December 7, 2020).

There were a few records from Koshi Barrage: a flock of 20 birds in breeding plumage was observed on 30 April 1982 (Fleming Sr. et al. 1984); one bird was seen on 2 May 1986 by Phil Heath (Heath 1986); 15 birds were seen on 15 April 1987 by Joel Heinen (Heinen 1988), and one bird was seen near the pink tower on 2 December 2000 (Dinesh Giri Pers. Comm., December 7, 2020). One bird was seen at Jagdishpur reservoir, Kapilvastu district on 28 January 2007 (Dinesh Giri Pers. Comm., December 7, 2020). One bird was observed feeding in the Dano River and in flight, Lumbini, Rupandehi district on 7 February 2009 (Dinesh Giri Pers. Comm., December 7, 2020).

\section{Greater sandplover Charadrius leschenaultii}

First recorded by Brian $\mathrm{H}$. Hodgson on 10 June in the $19^{\text {th }}$ century (year unknown) in the Kathmandu Valley (Hodgson 1829a, 1844). One bird was seen at Koshi Barrage on 11 February 1987 (Juliusberger 1987). Another bird was observed with a flock of 22 lesser sand plovers C. mongolus at Koshi Barrage on 11 May 1992 by Malcolm Ausden and Siobhan Mellon (Anonymous 1992a).

\section{White-tailed lapwing Vanellus leucurus}

There are more than 10 records of this species, so it can no longer be considered a vagrant. It is probably a regular winter visitor in small numbers, chiefly to the western lowlands.

First recorded in December 1952 at Bilauri, Kanchanpur district by R. L. Fleming Sr. Another was recorded there a month later and one was seen at Dhangadhi, Kailali district (Rand \& Fleming 1957).

Mainly recorded from the west. One was seen at Nepalganj, Banke district on 1 January 1977 by Stan Justice (Justice 1978) and by the Babai River near Ghurai, Dang-Deukhuri district from 7 to 10 January 1981 by Kathleen Munthe (Munthe 1981).

There are several records from Jagdishpur Reservoir, Kapilvastu district. One bird was seen on 28 February 2017 by Anil Gurung and three birds were seen there on 29 February 2017 by Ramesh Chaudhary and other Bird Education Society members (Tek Bahadur Gurung pers comm.). At the same locality, one bird was seen on 16 January 2018 (Dinesh Giri Pers. Comm., December 
7, 2020); one bird on 3 March 2020 by Hem Sagar Baral, Tika Ram Giri and Carol Inskipp (Inskipp 2020), and two birds between October 2019 and March 2020 (Bhusal et al. 2020).

The species has been recorded in the Shikari Tal marshes, Shuklaphanta National Park: a flock of 20 birds on 20 December 2016 by Devraj Joshi and 16 on 25 December 2016 by Pratap Gurung (Pratap Gurung Pers. Comm., November 17, 2020). Five birds were seen there on 17 February 2017 by Manshanta Ghimire, Rajendra Gurung, Pratap Gurung, Tek Gharti Magar, Tek Bahadur Gurung and Krishna Bidari (Tek Bahadur Gurung Pers. Comm., December 7, 2020). Six birds were seen there on 13 January 2019 by Ram Shahi, Hathan Chaudhary, Tek Gharti Magar, Yam Rawat and Hemanta Darai (Ram Shahi Pers. Comm., December 14, 2020).

Four birds were seen at Badhaiya Tal, Bardia district in 2018 by Manshanta Ghimire, Ram Shahi and Ganga Bahadur Ghale (Manshanta Ghimire Pers. Comm., December 7, 2020), one bird was seen there on 3 February 2019 (Dinesh Giri Pers. Comm., December 7, 2020) and three on 11 January 2020 by Ram Shahi and Bardia Nature Conservation Club team (Ram Shahi Pers. Comm., December 14, 2020).

One bird seen at Budhaulikuna Ghol, Lamichaur, Chitwan National Park buffer zone, Nawalparasi district on 7 December 2019 by Dhan Bahadur Chaudhary, is the furthest east record of the species in Nepal.

\section{Red knot Calidris canutus}

The first record was of a flock of 10 in transitional plumage on mudflats near Kusaha, Koshi Tappu Wildlife Reserve on 15 May 2000 seen by Doug E. Dickinson et al. (Giri \& Choudhary 2000a, Dickenson 2000); also seen here the following day by Dinesh Giri, Som GC and Gangaram Singh (Dinesh Giri Pers. Comm., December 7, 2020).

\section{Terek sandpiper Xenus cinereus}

First recorded by Richard F. Grimmett and Jonathon C. Eames at Koshi Barrage on 18 April 1982 (Eames 1982, Grimmett 1982). Also recorded on Gokyo Lake, Sagarmatha National Park at about $4710 \mathrm{~m}$ : two were seen on 2 May 1984 and one photographed the next day by Rob Tolk (Tolk 1988). Recorded in Chitwan National Park on 24 December 2000 by Matt Brady and Halle Brady (ebird)

\section{Red-necked phalarope Phalaropus lobatus}

The first record was of one seen on the Rara Lake shore, Rara National Park on 16 October 1982 by David Brearey and David Pritchard (Pritchard \& Brearey 1983). One was recorded on Phoksundo Lake, Dolpo district, Shey-Phoksundo National Park on 28 September 2008 by Andy Bluefield and Joni Bluefield (Bluefield \& Bluefield 2008).

\section{Whimbrel Numenius phaeopus}

There were more than 10 records of this species, so it can no longer be considered a vagrant. It is probably a rare passage migrant. First recorded by Brian $\mathrm{H}$. Hodgson from the Kathmandu Valley in August and September (years unknown) (Hodgson 1829a, 1844).

The species was also found in the Kathmandu Valley later: in the Bagmati pools in September 1989 by Sharifin Gardiner (Gardiner 1990) and one photographed at Siddhipur, Lalitpur on 8 September 2019 by Uvin Shrestha (ebird). One was seen at Koshi Barrage between February and April 1981 and 12 on 14 March 1982 (Walinder \& Sandgren 1983). Recorded in Koshi Tappu Wildlife Reserve on 8 March 1989 by Arun Bose (ebird). One was recorded by Phewa Lake in April 1981 by James Wolstencroft (Wolstencroft 1981).

In Chitwan National Park it was described as a rare passage migrant from April to September (Gurung 1983). The maximum of 22 birds was seen there on 10 May 1984 by Rob Innes and Paul Lewis (Innes \& Lewis 1984). One bird photographed in Chitwan National Park by BES members on 11 September 2017 was found by Suka Ram Mahato. One bird was sighted by Tika Ram Giri in Chitwan in April 2020 and one bird was seen by the Community Forest Road, Ratnanagar, Chitwan National Park on 25 May 2020 by Ramesh Chaudhary (ebird). Single birds were recorded in Chitwan National Park buffer zone: one bird was seen at Sauraha on 8 October 2013 by Tek Bahadur Gurung (ebird) and one bird was seen on 8 November 2013 at Kumroj Community forest by Tek Bahadur Gurung and Hari Lama (Tek Bahadur Gurung Pers. Comm., December 7, 2020).

An injured bird was caught near Kal Bhairab, Dailekh district near Lohore Khola on 21 September 2020 (Janak Chaudhary) (photos and video with call sent to Hem Sagar Baral). 


\section{Ruddy turnstone Arenaria interpres}

The first record was of one photographed on the gravel flats at Tukche, upper Kali Gandaki Valley, Annapurna Conservation Area on 14 September 1973 by Mark Beaman (Beaman 1973). Photographs of at least 12 birds were taken in Yangma village (previously Walangchungola VDC ward no 9 , now it is Faktanglung Rural Municipality ward no 7), Kanchenjungha Conservation Area at 4200m on 29 November 2015 (Hem Raj Acharya). One bird was observed on the Rapti River at Jaymangala Ghat, Chitwan on 9 January 2017 by Tika Ram Giri, Basu Bidari and other Bird Education Society members (Tek Bahadur Gurung Pers. Comm., December 7, 2020).

\section{Curlew sandpiper Calidris ferruginea}

First recorded by Niels Krabbe et al. who saw one bird in full breeding plumage at Koshi Barrage on 22 April 1981 (Krabbe 1981). Two birds were seen by the Bagmati River, Kathmandu on 25 October 1982 by John Halliday (Halliday 1983) and up to four birds were seen along the Rapti River, Chitwan National Park between 8 November and 28 December 1982 by Kaj Halberg and Ib Petersen (Halliday 1982, Halberg \& Petersen 1983). Recorded in Koshi Tappu Wildlife Reserve on 2 January 2000 by Algirdas Knystautas (ebird). Other records are from by the Rapti River, Sauraha, Chitwan National Park buffer zone on 7 March 2007 by S. Laurie (ebird) and in Bardia National Park on 6 March 2016 by Matthew Bockey (ebird).

\section{Long-toed stint Calidris subminuta}

First recorded by Robert L. Fleming Sr. on 11 May 1960; two or three birds accompanied a flock of Temminck's Stints on mudflats of the Bagmati River, Kathmandu Valley (Fleming \& Traylor 1961). The only other record is of four birds seen on 4 May 1982 at Rani Tal, Shuklaphanta National Park by Tim and Carol Inskipp (Inskipp \& Inskipp 1982)

\section{Sanderling Calidris alba}

The first record is of one seen on 11 February 1979 by F. Lambert et al. It accompanied a flock of 50 little stints $C$. minuta and nine dunlin C. alpina. This was apparently the first inland record of Sanderling for the Indian subcontinent (Lambert 1979, Redman \& Murphy 1979, Redman et al. 1984). Two birds were seen south of Koshi Barrage on 18 February 1993 by Martin Flack (Flack 1993, Lama 1994a).
One bird was observed in winter plumage on 18 February 2003 by the Rapti River, Charahara at Chitwan by Hathan Choudhary, Bishnu Mahato, D. R. Choudhary and Naturetrek group (Giri \& Choudhary 2003a).

One bird was observed by the Karnali River on 24 December 2012 by Hathan Chaudhary, Bird Education Society members and Bird Conservation Nepal members (Hathan Chaudhary Pers. Comm., November 10, 2020, Tek Bahadur Gurung Pers. Comm. December 7, 2020).

\section{Mew gull Larus canus}

First recorded at Koshi Barrage on 12 February 1979 by Richard Filby et al. It was still present on 21 February (Lambert 1979, Redman \& Murphy 1979, Redman et al. 1984). Single adults were seen at Phewa Lake on 21 January and 19 February 1981 by Adrian del-Nevo and Peter Ewins (del-Nevo \& Ewins 1981) and on 28 February 1983 by H. Nickel and R. Trost (Nickel \& Trost 1983). A first-year bird was seen at Koshi Barrage from 2-5 January 1993 by Jan Tottrup Nielsen (Lama 1993a).

\section{Slender-billed gull Larus genei}

First recorded by Paul A. Dukes et al. on 7 February 1974 at Koshi Barrage. The following day an immature was seen (Madge et al. 1974). There are several other records from Koshi Barrage. One to two birds were seen in February in 1975 (Gregory-Smith \& Batson 1976); 1979 (Lambert 1979, Redman \& Murphy 1979), and 1981 (Baker 1981, Mills \& Preston 1981). Also recorded there in January 1985 (Calladine 1985); in March 1987 (Stones 1987, Turin et al. 1987) and November 1989 (Nielsen \& Jakobsen 1989).

The only other record is of one photographed at Phewa Lake in November and December 2018 by Manshanta Ghimire and Amrit Kumar Poudel (Manshanta Ghimire Pers. Comm., December 3, 2020).

\section{Sooty tern Onychoprion fuscatus}

The only record is of one bird seen regularly flying over fishponds in Koshi Camp, Sunsari district from 15-17 July 2017. The bird which died later, was photographed by Anish Timsina and Sanjib Acharya (ebird) 


\section{Northern long-eared owl Asio otus}

First recorded by Brian $\mathrm{H}$. Hodgson from the Kathmandu Valley on 20 November (year unknown) in the $19^{\text {th }}$ century (Hodgson 1829a, 1837b). The next record was one bird was collected in the Kakani hills, central Nepal on 11 November 1962 by G. Diesselhorst (Diesselhorst 1968).

One bird (pale version) was seen at Pipar, Annapurna Conservation Area at 2745 m on 16 November 1999 by G. Foggitt and A. Powell (Foggitt 1999, Giri \& Choudhary 1999). The only other record is by Niraj Thakali: two birds videoed at Thini, Mustang, Annapurna Conservation Area in November 2020 (Raju Achyara in litt. to Hem Sagar Baral and Carol Inskipp, 2 November 2020).

\section{Indian vulture Gyps indicus}

There are more than 10 records of this species, so it can no longer be considered a vagrant. It is probably a rare but regular visitor (Tulsi Ram Subedi). First recorded at Jatayu Vulture Restaurant, Kawasoti municipality, Nawalparasi district on 1 December 2011 when two birds were observed and photographed by Tulsi Ram Subedi and a group of three Finnish and two American ornithologists (Giri \& Choudhary 2012, Subedi \& DeCandido 2013). Both individuals were seen regularly for about two weeks (Dhan Bahadur Chaudhary Pers. Comm., November 20, 2020). In subsequent years the species has been regularly recorded here between November and May e.g. single birds on 3, 5, 9 and 31 December 2019, and in 2020 on 18, 23 and 26 January, 2 and 10 February, 15 April and 20 May (Dhan Bahadur Chaudhary Pers. Comm., November 20, 2020).

There were two records from the Pokhara valley: one bird seen in the Dobilla area in 2013 by Tika Ram Giri and one bird seen flying over Nirmal Pokhara towards the Pokhara landfill site in December 2015 by Manshanta Ghimire and Hemanta Dhakal (Manshanta Ghimire Pers. Comm., December 3, 2020).

One bird was seen at the Rohini River, near Bhairahawa, Rupandehi district on 3 February 2017 by Anil Gurung and Mikael Hakke (Tek Bahadur Gurung Pers. Comm., December 7, 2020). One bird was seen flying over Lumbini on 3 March 2020 by Hem Sagar Baral, Tika Ram Giri and Carol Inskipp (Inskipp 2020). One bird was recorded at Jagdishpur Reservoir on 16 February 2020 by Som GC (Bhusal et al. 2020).

\section{Rufous-necked hornbill Aceros nipalensis}

The species was described for science from Nepal by Brian $\mathrm{H}$. Hodgson who collected it in the lower hills in the $19^{\text {th }}$ century (year unknown) (Hodgson 1829a,1829b, 1832, 1833b).

\section{Grey-breasted broadbill Serilophus rubropygius}

Only recorded by Brian $\mathrm{H}$. Hodgson in the $19^{\text {th }}$ century (Hodgson 1839). One of his specimens was from the lower hills on 10 January (year unknown) (Hodgson 1829a).

\section{Ashy minivet Pericrocotus divaricatus}

First recorded on 19 November 2011 when three birds were seen in the Prakashpur area at the edge of Koshi Tappu Wildlife Reserve by Badri Chaudhary and Hathan Choudhary (Giri \& Choudhary 2012a).

At Koshi Tappu Wildlife Reserve, a mixed flock of 10 ashy minivets and six Swinhoe's minivets $P$. cantonensis were seen on 2 November 2012 by Sanjib Acharya and Koshi Bird Society team (ebird). Four birds were seen there on 9 March 2013 by Tuija Pakkanen Suihkonen (ebird) and also recorded on 23 March 2015 by Martin Field (ebird). One bird was seen at Koshi Wildlife Camp, Koshi Tappu on 25 November 2017 (Tek Bahadur Gurung Pers. Comm., December 7, 2020).

A pair was sighted in Chitwan Gaida Lodge, Sauraha, Chitwan National Park buffer zone on 7 December 2012 by Tika Ram Giri (Giri \& Choudhary 2012b). Five birds were seen in Sauraha on 10 January 2013 by Tek Bahadur Gurung (ebird).

\section{Swinhoe's minivet Pericrocotus cantonensis}

The first record was of a mixed group of six Swinhoe's minivets with 10 ashy minivets $P$. divaricatus observed at Prakashpur, near Koshi Tappu Wildlife Reserve on 2 November 2012 by Sanjib Acharya and Koshi Bird Society team (ebird).

One bird was also seen and photographed in Prakashpur on 23 January 2020 by Sanjay Tha Shresta, Subas Bhujel, Ram Shankar Shrestha, Ram Moye and Ujal Jimma (Anonymous 2020) and also photographed by Sanjay Tha Shrestha on 4 Feb 2020 in Koshi Tappu Wildlife Reserve.

One male bird which was either Swinhoe's minivet or ashy minivet was photographed at Meghauli, Chitwan National Park buffer zone on 31 March 2020 by Ashik Gurung (Facebook). 


\section{Black-browed reed-warbler Acrocephalus bistrigriceps}

First recorded by Jim Hall who saw one in the Koshi marshes on 19 January 1981 (Hall 1981). Single birds were also found there on 17 March 1982 by Mick Turton and Graham Speight (Turton and Speight 1982) and on 23 February 1983 by Tony Baker (Baker 1983).

\section{Moustached warbler Acrocephalus melanopogon}

The first record was one was seen on 22 December 2002 and three birds on 24 and 25 December 2002 at Rani Tal marshes, Shuklaphanta National Park by Hem Sagar Baral, Tika Ram Giri, Badri Chaudhary and Som GC One individual was trapped and photographed there on 25 December (Baral et al. 2003).

One bird was photographed by Aashish Shrestha in the grassy area on the east side of Jagadishpur Reservoir, Kapilvastu district on 3 February 2017 (Shrestha 2017). One to three birds were regularly sighted on northern side of Jagdishpur in the Typha reeds between 2014 and February 2020 (Som GC Pers. Comm., November 27, 2020).

\section{Oriental reed-warbler Acrocephalus orientalis}

A specimen was collected near Biratnagar, Morang district on 9 March in $20^{\text {th }}$ century (year unknown) by Robert L. Fleming (Fleming Sr. et al. 1979).

One bird was seen on 15 April 1997 and another trapped on 19 April 1997 at Koshi Tappu Wildlife Reserve by Hem Sagar Baral, Guido Kejil, Badri Chaudhary and B. Rayamajhi (Giri \& Choudhary 1997).

\section{Pallas's grasshopper-warbler Locustella certhiola}

First recorded by Frank M. Bailey who collected a specimen by the Koshi River in the terai on 12 February 1937 (Bailey 1938). One bird was also seen at Koshi on 17 March 1982 by Mike Parr (Parr 1982). and two birds there on 7 April 1986 by P. Holt, R. Crossley and C. Moores (Holt et al. 1986). One bird was observed by the Bagmati pools, Kathmandu Valley on 26 October 1989 by Sharifin Gardiner (Gardiner 1990).

\section{Lanceolated warbler Locustella lanceolata}

First recorded by Frank M. Bailey who collected a specimen from the eastern terai at San Pakwa, Morang district on 23 February 1938 (Bailey 1938, Biswas 1968). Single birds were seen in Shuklaphanta National Park on 2, 4 and 5 May 1982 by Tim and Carol Inskipp (Inskipp \& Inskipp 1982). One bird was observed in
Chitwan National Park on 19 April 1983 by Per Alström and Urban Olsson (Alström \& Olsson 1983) and one on 4 March 1986 by Steve Madge and Nigel Redman (Madge \& Redman 1986).

One bird was recorded at Koshi Barrage in late January 1987 by S. Nicolle (Nicolle 1987). A specimen from the Babai River, originally identified as this species (Fleming Sr et al. 1979), was later reidentified as common grasshopper-warbler $L$. naevia by the Chicago Field Museum (Anonymous 1983).

\section{Brown grasshopper-warbler Locustella luteoventris}

The species was described for science from Nepal by Brian $\mathrm{H}$. Hodgson (Hodgson 1845). He obtained specimens from the northern hills in the $19^{\text {th }}$ century (Hodgson 1829a). There are no later records.

\section{Himalayan grasshopper-warbler Locustella kashmirensis}

This species probably breeds in the high Himalayas of Nepal and has been recorded several times in winter in the lowlands, so it may be an altitudinal migrant. Further surveys are required to determine its true status in Nepal.

Himalayan grasshopper-warbler was split as a separate species from spotted grasshopper-warbler L. thoracicus by Alström et al. (2008). The possibility that Brian Houghton Hodgson had the first record of this species is discussed in Arora et al. (in prep.).

There were three breeding season records of 'Bradypterus thoracicus' from Nepal. However, no photographs or sound recordings were made of these birds and none provided enough information to exclude the possibility that they might be referrable to kashmirensis. These three records are: a nest and eggs found at $3850 \mathrm{~m}$ on Lamjung Himal on 22 July 1977 (Thiollay 1977, 1980); the species was found to be common on the ridge west of the Mardi Khola Valley at $3350 \mathrm{~m}$ in June (1978-1981 - year not clear) (Lelliott 1981); and a fledgling specimen was collected from the Chyul-wang Valley, at $3400 \mathrm{~m}$ in north-central Nepal on 03 August 1983 (Martens \& Eck 1995).

The first definite record of Himalayan grasshopper-warbler was by Hem Sagar Baral (HSB) on 18 May 1997, who taped one bird while recording bird sounds at Rani Tal marshes in present-day Shuklaphanta National Park. HSB noted the bird was "an unidentified warbler"; in September 2018, Gunjan Arora identified it as Himalayan grasshopper-warbler (Pers. Comm., to HSB September, 2018, Arora et al. in prep).

One bird was photographed by Hathan Chaudhary and seven birds heard singing on 7 August 2016 between Machhapuchhre 
Base Camp and Annapurna Base Camp, Annapurna Conservation Area from $3960 \mathrm{~m}$ to $4100 \mathrm{~m}$ (Giri \& Chaudhary 2016, Inskipp \& Chaudhary 2016, Chaudhary \& Inskipp 2017). At the same location six to seven birds were heard singing and three were seen on 6 and 7 September 2016 (Manshanta Ghimire Pers. Comm., December 3, 2020).

One bird was tape recorded and photographed on 22 May 2017 and one bird was photographed with nesting material on 25 May 2017 in Pipar, Kaski district, Annapurna Conservation Area by Hathan Chaudhary (eBird).

On 4 February 2017, three birds were heard at Jagadishpur Reservoir, Kapilvastu district by Hem Sagar Baral and Carol Inskipp. Two birds were seen and one photographed in Typha spp. on the northern side of Jagdishpur by Som GC on 24 February 2018 (GC in Oriental Bird Images 2018) and one seen in the same area on 16 February 2019 (Som GC Pers. Comm., November 27, 2020).

On 5 February 2018 in a small marshy patch of Typha in agricultural fields, three birds were located, taped and photographed by HSB at Lumbini, Rupandehi district (Hem Sagar Baral and Carol Inskipp Pers. Obs.). Two birds were heard by the Telar River near Lumbini, Rupandehi district on 3 March 2020 by Tika Ram Giri, Hem Sagar Baral and Carol Inskipp (Inskipp et al. 2020).

One was heard at Jhilmila, Shuklaphanta National Park on 11 March 2020 by Tika Ram Giri, Devraj Joshi, Yam Rawat and Carol Inskipp (Inskipp et al. 2020). Spotted grasshopper-warbler Locustella thoracicus was recorded in Chitwan National Park, Koshi Tappu Wildlife Reserve and at Koshi Barrage before this species was split (e. g. Baral 2005). However, the re-identification of these birds as Himalayan grasshopper-warbler cannot be ruled out.

\section{Common grasshopper-warbler Locustella naevia}

The first record was a specimen obtained near the Babai River, Bardia district in April 1972 by Robert L. Fleming (Fleming Sr. et al. 1979). One was ringed at Koshi Barrage on11 April 1976 by Richard Gregory-Smith and Francis Batson (Gregory-Smith \& Batson 1976). Another individual was seen there on 8 April 1983 by Per Alström and Urban Olsson (Alström \& Olsson 1983). One or two birds were seen in Chitwan National Park on 13 April 1985 by Tim Andrews (Andrews 1986).
One was seen in the main phanta at Shuklaphanta National Park on 23 April 2001 by Tim and Carol Inskipp (Giri \& Choudhary 2001).

\section{Baikal grasshopper-warbler Locustella davidii}

The only record is one bird trapped by Philip Round and Hem Sagar Baral 9 May 2012 at Koshi Camp, Madhuban, Sunsari district on 9 May 2012 (Round \& Baral 2013).

\section{Asian stubtail Urosphena squameiceps}

The first record was of one bird seen by Alan Lewis in forest between Itahari and Dharan, Sunsari district on 21 January 1993 (Lama 1993b, Lewis 1994).

\section{Mountain chiffchaff Phylloscopus sindianus}

The first record is of one photographed on 25 March 2018 on the northern bank of Phewa Lake by Benny Fredriksson and confirmed as a new bird for Nepal (Benny Fredriksson in litt. to Tim and Carol Inskipp, April 2018).

Two birds were observed in bushes, by the Seti Khola near Waterfront Resort, Pokhara valley in January 2019 (Manshanta Ghimire/Pokhara Bird Society team).

\section{Radde's warbler Phylloscopus schwarzi}

First recorded north of Charali in the east at $150 \mathrm{~m}$ where one was seen on 25 December 1979 by Richard Fairbank (Fairbank 1980). One was also recorded at Pokhara on 4 and 5 March 1983 by Tony Baker (Baker 1983. However, both observers have now withdrawn their records (Jayapal et al. 2017). The only record from Nepal is one seen at Pokhara on 4 March 1986 (Alind 1986).

\section{Hume's whitethroat Sylvia althea}

One was trapped at Kosi Bird Observatory by Hem Sagar Baral and Tony Mainwood on 5 October 2014. The same bird was trapped again on 9 January 2016 at the same locality by Tony Mainwood. [The bird was first noticed to be different from Lesser Whitethroat Sylvia curruca based on its unusually long $(71 \mathrm{~mm})$ wing-length. It also had other morphometrics and physical characters different to S. curruca.] (Himalayan Nature 2020b) These constitute the first and only records for Nepal.

\section{Eastern Orphean warbler Sylvia crassirostris}

First recorded in spring 1975 at Shuklaphanta National Park by Robert L. Fleming Sr. (Fleming Sr. 1977). One bird was seen at Chitwan on 11 November 1975 by Richard Byrne and S. W. 
Harris (Byrne \& Harris 1975). One bird was observed at Koshi Tappu Wildlife Reserve on 9 March 1989 by Tim Dodman and Yvonne Guinan (Dodman \& Guinan 1989).

One bird was seen on an island near Kosi Bird Observatory on 07 March 2013 by Sanjib Acharya and Kosi Bird Observatory group (ebird). Two birds were seen on an island near Kosi Bird Observatory on 27 February 2014 by Dinesh Ghimire (ebird) and one bird was seen there on 27 March 2019 by Dheeraj Chaudhary (ebird).

\section{Black-breasted parrotbill Paradoxornis flavirostris}

The species was described for science for Nepal from a Hodgson specimen by John Gould (Gould 1836, Warren \& Harrison 1971). Although not included in the catalogues of Hodgson's collections (Hodgson 1844, Gray \& Gray 1846, Gray 1863); a specimen was subsequently listed as collected in the Nepal terai (Sharpe 1883).

\section{Red-faced liocichla Liocichla phoenicea}

This is a very rare and very local resident that was re-found in Nepal after the publication of the Nepal Red List (Inskipp et al. 2016). The species was described for science from Nepal by John Gould (Gould 1837-38), probably from a Brian H. Hodgson specimen. It was first recorded from Nepal by Brian $\mathrm{H}$. Hodgson (Gray \& Gray 1846); no details are available on the specimen's date and location.

The first record of the species since the $19^{\text {th }}$ century was on 21 May 2016 in Darhakhani Chisapanitar forest by Hem Sagar Baral, Raju Tamang, Tika Ram Giri, Basu Bidari, Badri Chaudhary, Bishnu Mahato, Ramgir Mahato, Som Bahadur Tamang, Fuleshwar Chaudhary and Rupendra Karmacharya. Eight birds were seen (Giri \& Choudhary 2016, Baral et al. 2018).

Subsequently the species has been seen regularly in this area, but only in very small numbers. Records include 10 birds on 27 May 2017 by Hathan Choudhary (ebird); six birds on 13 December by Raju Tamang (Tek Bahadur Gurung Pers. Comm., December 7, 2020); seven birds on 6 February 2019 by Carol Inskipp, Tika Ram Giri and Raju Tamanag (ebird), and two on 28 February 2020 by Sanjib Acharya and Prem Thapa (ebird). Breeding was proved by Raju Tamang in 2018 (Tek Bahadur Gurung Pers. Comm., December 7 2020).

\section{White-shouldered starling Sturnus sinensis}

The only record is of one bird seen amongst a flock of Chestnuttailed Starlings in north-eastern Koshi Tappu Wildlife Reserve from 26-29 September 2010 by Badri Chaudhary and Anish Timsina (Giri \& Choudhary 2011).

\section{Purple-backed starling Agropsar sturninus}

The first record was of a male and female birds seen at Koshi Camp near Koshi Tappu Wildlife Reserve on 10 May 2002 by Suchit Basnet and Badri Choudhary; five males and 1 female were seen there the following day (Basnet \& Choudhary 2002).

Five birds were seen on 7 May 2008 and two on 10 May 2008 at Koshi Tappu Wildlife Reserve by Tika Ram Giri, Badri Chaudhary, Som GC, Anish Timsina) (Giri \& Choudhary 2008).

\section{Asian glossy starling Aplonis panayensis}

A subadult male was seen feeding in a palm tree with common mynas Acridotheres tristis and chestnut-tailed starlings Sturnus malabaricus in Koshi Camp garden, near Koshi Tappu Wildlife Reserve on 18 May 2003 by Badri Chaudhary, Raju Tamang and Anish Timsina (Choudhury 2003). This is the only Nepal record.

\section{Green cochoa Cochoa viridis}

The species was described for science from Nepal by Brian $\mathrm{H}$. Hodgson (Hodgson 1836c). He obtained at least four specimens from the lower hills in June (year unknown) in the $19^{\text {th }}$ century (Hodgson 1829a)

\section{Grey-sided thrush Turdus feae}

The only record is one bird seen and photographed with one eyebrowed thrush Turdus obscurus on 23 December 2015 at Simbhanjyang, Makawanpur District by Som GC and Mich Coker (Giri \& Choudhary 2016, Mich Coker ebird).

\section{[Black-breasted thrush Turdus dissimilis}

There are two reports of this species from Nepal, but they still need to be discussed by the Nepal Rare Birds Committee and further confirmation is probably required of the species' occurrence in Nepal.

One was seen on 25 February 2000 near Koshi Camp, close to Koshi Tappu Wildlife Reserve by Ramesh Karki and Kiran Shrestha but only brief details are available. (Giri \& Choudhury 2000a). One was seen very briefly by Tika Ram Giri and very briefly and inadequately by Carol Inskipp on 11 March 2020 at Radhapur in Shuklaphanta National Park (Inskipp et al. 2020), Giri et al. in press] 


\section{Brown-breasted flycatcher Muscicapa muttui}

First recorded by Sudhir Vyas who saw one bird at Rani Bari, Kathmandu Valley at about 1330 m on 6 September 1987 (Vyas 1988) and another bird at Chatra in the east at about $135 \mathrm{~m}$ on 4 October 1987 (Vyas 1988). One bird was observed by Tek Gharti Marar and Pratap Gurung in Nagarjun forest near to the Kalij farm, Shivapuri Nagarjun National Park on 16 August 2017 (Pratap Gurung Pers. Comm., November 17, 2020).

Single birds were recorded in Rani Bari Community Forest, Kathmandu: photographed on 17 August 2017 by Pratap Gurung (ebird) and also observed by Tek Gharti Magar and Ramesh Chaudhary (Manshanta Ghimire Pers. Comm., December 3, 2020 and Tek Bahadur Gurung Pers. Comm., December 7, 2020). Seen on 13 August 2019 by Sanjib Acharya and Hem Katuwal (ebird, Facebook) and photographed by Aditya Pal (Facebook). Photographed on 20 and 31 August by Samyam Rumba (ebird); on 25, 28 and 31 August by Prasan Shrestha (ebird), and on 31 August by Friends of Bird, Rajendra Gurung, Amrit Nepali, Arend van Riessen, Krishna Thapa and Vimal Thapa (ebird), and also seen on 31 August by Hem Bd. Katuwal and Aditya Pal (Facebook).

Two birds were photographed in the Kathmandu Valley on 6 September 2019 by Jan de Groot (ebird). One bird was photographed on the northern hill of Lakeside, Methlang, Pokhara valley in August 2019 by Manshanta Ghimire and Pokhara Bird Society Team: Ananda Baral, Hira Malla, Shes Kanta Sharma, Durga Timilsina, Kushal Neupane, Salin Dhakal (Manshanta Ghimire Pers. Comm., Decemberr 3, 2020).

\section{Siberian blue robin Larvivora cyane}

An adult male was seen on 29 November 1985 at Nagarjun, Shivapuri Nagarjun National Park, Kathmandu Valley at about $1450 \mathrm{~m}$ by Robert Roberts (Roberts 1985). Another adult male was seen above Chitre, Annapurna Conservation Area on 17 March 1993 by Martin Flack (Flack 1993, Lama 1994b). An adult male was observed in Dharan forests Important Bird and Biodiversity Area, Sunsari district on 27 March 1997 by Badri Choudhary and Hathan Choudhary (Giri \& Choudhary 1997).

\section{Daurian redstart Phoenicurus auroreus}

First recorded on a Koshi River island on 25 December 2008 by Tika Ram Giri and Barry McCarthy (Facebook). A female was seen on various dates in May 2009 at Koshi Tappu Wildlife
Reserve by Tika Ram Giri, Barry McCarthy, Suchit Basnet, Som GC, Badri Chaudhary, Anish Timsina, Sanjib Acharya, Hem Sagar Baral and Hathan Choudhary (Giri \& Choudhary 2009); also recorded by Sanjib Acharya for the same site on 5 May 2009 (ebird). Two females were observed between Phale and Gyabla, Kanchenjungha Conservation Area on 10 April 2011 amongst flocks of blue-fronted redstart Phoenicurus frontalis (Baral 2011). There were three records from Sagarmatha National Park. One was photographed at Namche in May 2014 (Tek Bahadur Gharti Magar Facebook). Two were seen at Chhukum village on 5 November 2015 by Shes Kanta Sharma, Aaron and Marilyn Perlmutter) and one was seen at Pheriche in September 2018 by Manshanta Ghimire (Manshanta Ghimire Pers. Comm., Decenber 3, 2020).

\section{Rufous-tailed rock-thrush Monticola saxatilis}

The only record is of one photographed on 27 May 2016 in upper Dolpa district, near Shey monastery in Shey Phoksundo National Park, on a slope $(4781 \mathrm{~m})$ covered by alpine grassland and seen by Naresh Kusi, Tshiring Lhamu Lama and Pema Rikzin Lama and Geraldine Werhahn (Giri \& Choudhary 2016, Kusi et al. 2017).

\section{Northern wheatear Oenanthe oenanthe}

The only record is of an adult male seen on 1 April 1983 at Meghauli, Chitwan by Clive Byers and Adam Adams (Byers \& Adams 1983)

\section{Pied wheatear Oenanthe pleschanka}

The first record was of probably a first-year male, seen at Tukche in the upper Kali Gandaki valley, Annapurna Conservation Area at $2590 \mathrm{~m}$ on 11 January 1985 by Tim Andrews (Andrews 1986). A male was seen on 31 May 1993 at Thare Pati, Langtang National Park on 26 May 1993 by Nigel Redman (Lama 1993a, Redman 1993). One was recorded on 20 November 2018 in Katari, Udaypur district by Anish Timsina (Facebook).

\section{Spanish sparrow Passer hispaniolensis}

First recorded at Koshi Barrage where a flock of 50 birds was seen on 16 February 1981 by David G. H. Mills et al. (Baker, T. 1981, Mills \& Preston 1981).

The other records are also from Koshi: up to three birds were seen in mid-March 1982 (Robson 1982, Turton \& Speight 1982). Three males and three females were seen there on 20 January 
1994 by Tika Ram Giri, Guy Thompson and Duncan Orr-Ewing and one was seen on 23 February 1994 by Krishna Karki (Lama 1994c). At least three males showing intermediate features between Spanish and house sparrows Passer domesticus were observed in a party of about 20 sparrows at Koshi on 17 and 18 February 1981 (del-Nevo \& Ewins 1981).

The only other record is of one bird seen with house sparrows at Kusaha, Koshi Tappu Wildlife Reserve on 29 January 2000 (Dinesh Giri Pers. Comm., December 3, 2020).

\section{White-rumped snowfinch Onychostruthus taczanowskii}

The first record is of one collected at Neachachung, Mustang, Annapurna Conservation Area at 4815 m on 13 June 1977 by Hari Sharan Nepali (Nepali 1982). Three birds were seen and one photographed on 22 October 2005 at Kalopani, Annapurna Conservation Area at $2530 \mathrm{~m}$ by Mark Mallalieu. The birds were seen after a period of unusually heavy snow for the time of year that fell on 19 October (Inskipp 2006).

\section{Plain-backed snowfinch Pyrgilauda blanfordi}

The first record was of one collected at Neachachung, Mustang, Annapurna Conservation Area at 4815 m on 13 June 1977 by Hari Sharan Nepali (Nepali 1982). There are two other records from Mustang: two birds at Lomanthang in 2016 (Tek Bahadur Gharti Magar) and two photographed on 3 July 2019 at Korala by Samjhana Karki (Facebook).

Eight birds were observed at Manang, Annapurna Conservation Area in October 2016 (Manshanta Ghimire Pers. Comm., December 3, 2020). There are two records from Sagarmatha National Park: two birds were observed and one photographed on 18 October 2012 near Khumjung by Mangesh Prabhulkar (ebird) and three were at Machhermo in 2014 (Tek Bahadur Gharti Magar Facebook).

\section{Grey-headed bullfinch Pyrrhula erythaca}

A flock of nine female birds was seen in Nagarjun forest, Shivapuri-Nagarjun National Park, Kathmandu Valley by Andy J. Booth and subsequently by other group members on 15 February 1996 (Giri \& Choudhary 1996). This is the only record for Nepal.

\section{Mongolian finch Bucanetes mongolicus}

First recorded by Robert L. Fleming Jr. who found a flock of 16 birds in the Muktinath valley, Annapurna Conservation Area at 3505 m on 25 June 1976 (Fleming Sr. et al. 1979).
There were two reports during the particularly severe winter of 1982: a party of 34 birds was seen near Jomsom on 8 February by Peter Pyle (Pyle 1982) and one bird on 9 February seen by Mike Parr (and Craig Robson (Parr 1982, Robson 1982).

A flock of 20 birds was seen at Jomsom on 8 March 1994 and 25 at Kagbeni on 9 March 1994; two weeks later 50 birds were seen at Kagbeni by Raf Drijvers (Drijvers 1995, Lama 1994b). A flock of 175 birds was observed on the flats south of Lo Manthang, Mustang, Annapurna Conservation Area by Mich Coker on 20 April 2017 (ebird).

\section{Common linnet Linaria cannabina}

The first record was of small flocks in Jumla district between 2370 m and $2410 \mathrm{~m}$ in January and February 1971 by Robert Fleming Sr. and Robert Fleming Jr. (Fleming Sr. \& Fleming Jr. 1971, Fleming Sr. et al. 1979). The only other record is of one bird seen at Bhoudigaon, south of Jumla on 14 January 1977 by Stan Justice (Justice 1978).

\section{Eurasian siskin Spinus spinus}

The first record was a male seen at Nagarjun, Shivapuri-Nagarjun National Park, at 1500 m on 7 April 1982 by Colin Winyard et al. (Fairbank 1982, Mills et al. 1982). A flock of seven birds was observed at Chhekampar, Tsum Valley, Manaslu Conservation Area, in December 2017 by Tek Bahadur Gharti Magar, Phurkel Sherpa and Asal Tamang (Manshanta Ghimire Pers. Comm., December 3, 2020).

\section{Red-headed bunting Emberiza bruniceps}

The first record was of a male seen along the Narayani River, Chitwan National Park at about 130 m on 15 April 1975 by Robert L. Fleming and Harry Gilston (Fleming Sr. et al. 1979, Gurung 1983). An adult male was seen in a flock of about 50 buntings, mainly yellow-breasted buntings, E. aureola also two blackheaded buntings $E$. melanocephala and two black-faced buntings E. spodocephala in Koshi Tappu Wildlife Reserve on 18 February 2002 by Suchit Basnet, Aaron Ofner and Graham Tebb (Tebb et al. 2002, Inskipp 2004, Tebb et al. 2004).

A pair was seen in Koshi Camp grasslands, near Koshi Tappu Wildlife Reserve on several dates in February 2002 by Som GC, Badri Chaudhary and Tika Ram Giri (Giri \& Choudhary 2002). One male was seen in Lumbini, Rupandehi district in January 2006 by Mark Mallalieu and Hem Sagar Baral (Hem Sagar Baral Pers. Obs.). One bird was seen with two black-headed buntings 
E. melanocephala in Chitwan National Park on 28 February 2014 by Lei Zhu (ebird).

\section{Chestnut bunting Emberiza rutila}

The only record is of one collected at Godavari, Kathmandu Valley at $1525 \mathrm{~m}$ in January 1954 by Robert L. Fleming Sr. (Rand \& Fleming 1957).

\section{Yellowhammer Emberiza citrinella}

First recorded at Kagbeni, Annapurna Conservation Area at 2810 m on 25 February 1981 by Tony Baker, David Mills and Nick Preston (Baker 1981, Mills \& Preston 1981). There were several reports from the upper Kali Gandaki valley, Annapurna Conservation Area between January and early April in most winters between 1981 and 1987 chiefly of a few birds between Kalopani and Jomsom from $2630 \mathrm{~m}$ to $2745 \mathrm{~m}$. There was also one record at $1100 \mathrm{~m}$ at Tatopani (Turton \& Speight 1982). The maximum recorded was six birds at Jomsom in January 1983 seen by Werner Suter (Suter 1983). The only other confirmed record is of one or two birds seen at Jumla on 26 January 1983 by David Brearey and David Pritchard (Pritchard \& Brearey1983).

\section{Grey-necked bunting Emberiza buchanani}

The first record was of one photographed feeding on open ground amongst scattered bushes on 20 April 2010 at the edge of Shuklaphanta National Park by Anish Timsina and Dheeraj Chaudhary (Giri \& Choudhary 2010b)

Single birds were photographed on 24 September 2014 in Sauraha, Chitwan National Park buffer zone by a Bird Education Society team (Facebook) and on 22 September 2015 at Hattisar, Sauraha (Sagar Giri Pers. Comm., September 23, 2015). One was seen near Sukibhar guard post, Chitwan National Park on 13 November 2017 by Dinesh Giri, and Mike Barth on 13 November 2017 (Dinesh Giri Pers. Comm., December 3, 2020).

\section{White-capped bunting Emberiza stewarti}

The first record was of a specimen collected by Frank M. Bailey at Banbasa, Kanchanpur district at $75 \mathrm{~m}$ on 7 January 1937 (Bailey 1938). Single specimens were also collected in the west at Tansen, Palpa district at $1370 \mathrm{~m}$ in December 1951 and at Barmdeo Mandi, Mahakali at 290 m in January 1953 by Robert Fleming Sr. (Rand \& Fleming 1957). One bird was photographed in February 2017 in Kavre village, Dang district by Hari Basnet (Facebook).

\section{Rustic bunting Emberiza rustica}

The first record was of a male seem at Sauraha, Chitwan National Park buffer zone on 31 January 1981 by Adrian del-Nevo and Peter Ewins (del-Nevo \& Ewins 1981, 1983). Another male was recorded at Kagbeni, Annapurna Conservation Area at about 2810 m on 25 February 1981 by Tony Baker (Baker 1981). Two were seen at Pokhara on 25 December 1989 by Russell Slack (Slack 1990).

\section{[Common reed bunting Schoeniclus schoeniclus}

After recent consideration, the record of two birds seen at Begnas Lake, Kaski district on 20 December 1970 (Inskipp 1971) has been withdrawn (Tim Inskipp in litt. to Carol Inskipp, 14 December 2020). The first record is one photographed/videoed by the Manohara River, Kathmandu Valley by Sanjay Tha Shrestha, first seen on 6 December 2020, later seen by Hem Sagar Baral, Gopi Shrestha, Manshanta Ghimire, Sanjib Acharya, Shankar Tiwary, Chungba Sherpa et al. and still present on 13 December 2020. This record is still to be considered by the Nepal Rare Birds Committee.]

\section{[Striolated bunting Emberiza striolata}

An adult was observed and photographed by Karan Giri and also seen by Asma Gurung on 18 October 2018, in the grounds of Barahi Jungle Lodge, Meghauli, Chitwan National Park buffer zone (ebird). This species is still to be considered by the Nepal Rare Birds Committee.]

\section{4 | Discussion}

The pattern of bird records under individual species accounts in this paper reveals how bird studies have changed since records were first made of Nepal birds in the $19^{\text {th }}$ century. Brian Houghton Hodgson, the British Resident in Nepal was the first person to study Nepal's birds. As he was not allowed to leave the Kathmandu Valley, he sent out teams of Nepalese trappers to bring birds back for him from all over the country. While he kept a small number of these birds live in captivity and was interested in their habits, his main study was of bird specimens and he recorded 665 bird species for the country for the first time (Cocker \& Inskipp 1988). A total of 19 of the 92 bird species assessed here were first recorded in Nepal by Hodgson.

Between the late 1930s and early 1970s a small number of foreign ornithologists, notably Frank Bailey, Biswasmoy Biswas, 
Dillon Ripley, Robert Fleming Sr. and Robert Fleming Jr., studied birds in Nepal. They had much more freedom to travel in the country than Hodgson and collected a huge number of specimens of a large number of species. Undoubtedly these early ornithologists made great advances in knowledge of Nepal's birds. A total of 17 of the 92 species assessed here were first recorded in Nepal during this period.

Between the 1970s and late 1990s there was an influx of western field birders who had developed a great interest in birdwatching at home and were excited to look for new species in Nepal. These birders focused on observing birds in their habitats and mainly recorded them with field notes and sketches. They also made a significant contribution to Nepalese ornithology, a total of 28 of the 92 species listed here were recorded during this period by foreign birdwatchers.

Hari Sharan Nepali made a huge contribution to Nepalese ornithology between the late 1960s and 1990s and found several new species for the country.

Since the 1980s there has been an enormous growth in bird research, and bird watching in Nepali society and this interest is still increasing. This has led to a huge increase in the number of bird records as illustrated by a number of species accounts in this paper, for example those of fulvous whistling-duck, bean goose and white-tailed lapwing. Improved field equipment (binoculars and telescopes) and better field guides have been a great aid and have led to much increased and impressive national expertise. Most recently a number of bird photographers have emerged who have contributed significantly to the understanding of Nepalese ornithology. A total of 22 of the 92 species assessed here were first recorded by Nepalis and nowadays most Nepal bird firsts are recorded by nationals.

Despite all the advances in our knowledge of Nepal's birds since the $19^{\text {th }}$ century, there is still high potential to find new species for the country. It is very heartening to note that many Nepali birdwatchers and photographers have a great concern at heart for conservation of the country's birds and bird habitats.

\section{5 | Conclusions}

Of the 92 species assessed, six are no longer considered vagrants as there are now more than 10 records of each; we recommend that national red list assessments are made for these species. Some of them may have always been rare residents or rare visitors, but due to paucity of data, they were previously considered vagrants. There are currently 71 vagrant species in Nepal. An additional four vagrants have still to be accepted by the Nepal Rare Birds Committee before they can be officially included on the Nepal bird list.

Nine species have so far not been recorded since the $19^{\text {th }}$ century. Previously, red-faced liocichla was amongst them, but this species was re-found in 2016 after the National Bird Red List was published. It is a very rare and very local resident. Himalayan grasshopper-warbler is now considered a separate species (instead of a subspecies) and is probably a breeding altitudinal migrant in Nepal. It was also concluded there is still high potential to find new bird species for Nepal, especially of passerines and in the less explored parts of the country.

\section{6 | Research implications}

While knowledge about Nepal's birds has increased enormously in recent years, there are still large parts of the country which have been little studied ornithologically, especially in the high mountains and outside the protected areas' system. These areas deserve much further study. This assessment has highlighted that passerine birds, especially small or skulking species, have been much less recorded than the larger non passerines. More survey effort to locate passerines, especially the more elusive birds is needed.

As well as adding important information about the distribution and status of birds known to occur in Nepal, the surveys recommended here are highly likely to find new species for the country. There has been a huge growth in Nepal bird photography in recent years. However, recording of birds' songs and calls is arguably just as important in bird identification and has so far taken place to a much smaller degree in the country. There is high potential to systematically make recordings of the sounds of Nepal's birds.

\section{Acknowledgements}

We are grateful to the numerous observers who have generously shared their bird records with us and for their companionship in the field. It is not possible to name everyone here, but special thanks go to Tim Inskipp for his sound advice and encouragement and to Tek Bahadur Gurung who collated the many records from the Bird Education Society and authenticated some records. We also thank, Hemanta Acharya, Raju Acharya, Hari Basnet, Suchit Basnet, Bimita Bhandari, Basu Bidari, Badri Chaudhary, Daya 
Chaudhary, Dhan Bahadur Chaudhary, Dheeraj Chaudhary, Fule Chaudhary, Rajan Chaudhary, Ramesh Chaudhary, Som GC, Dinesh Ghimire, Prashant Ghimire, Yadav Ghimirey, Tika Ram Giri, Sagar Giri, Pratap Gurung, Sandesh Gurung, Seejan Gyawali, Ian Hearn, Devraj Joshi, Rupendra Karmacharya, Naresh Kusi, August Rush Lama, Tek Bahadur Gharti Magar, Bishnu Mahato, Ram Krishna Mahato, Mitra Pandey, Doma Paudel, Laxman Poudyal, Sunaina Raut, Yam Rawat, Arend van Riessen, Ram Shahi, Shes Kanta Sharma, Gopi Shrestha, Sanjay Tha Shrestha, Uvin Shrestha, Paras Singh, Tulsi Ram Subedi, Raju Tamang, Jyotendra Jyu Thakuri, Umang Jung Thapa, Utsab Jung Thapa, Prem Thapa, Raju Thapa, Anish Timsina and Shankar Tiwary.

\section{Authors' contributions}

Inskipp, C. conceived and led most of the writing, carried out most of the consultations and extracted many e-bird records; Baral, $\mathrm{H}$. $S$. helped collect records through social media, provided some of his own records and helped with the writing; Acharya, S. helped collect records through the social media and provided many of his own records; Chaudhary, H., Ghimire, M. and Giri D. provided many records and authenticated some other records.

\section{Conflicts of interest}

Authors declare no conflict of interest.

\section{ORCID}

Carol Inskipp (iD https://orcid.org/0000-0002-6067-2525 Hem Sagar Baral iD https://orcid.org/0000-0002-9810-5104 Sanjib Acharya iD https://orcid.org/0000-0003-2567-8910 Hathan Chaudhary (D) https://orcid.org/0000-0003-4667-7968 Manshanta Ghimire iD https://orcid.org/0000-0001-5120-4351

\section{References}

Alind, P. 1986. Notes on birds recorded in Nepal, February - March 1986. Unpublished. Depositary: Library of Carol Inskipp.

Alström, P. and Olsson, U. 1983. Notes on birds recorded in Nepal, 1983. Unpublished. 13 pp. http://himalaya.socanth.cam.ac.uk/collections/inskipp/1983_002.pdf Accessed on 5 November 2020.

Alström, P., Rasmussen, P., Olsson, U. and Sundberg, P. 2008. Species delimination based on multiple criteria: the Spotted Bush Warbler Bradypterus thoracicus complex. Zoological Journal of the Linnean Society 154:291-307.
Andrews, T. 1986. Notes on birds recorded in northern India and Nepal 1984-1985, unpublished. http://himalaya.socanth.cam.ac.uk/collections/inskipp/1985_020.pdf Accessed on 5 November 2020.

Anonymous 1983. List of bird specimens collected by R. L. Fleming Sr. and R. L. Fleming Jr. from Nepal 1965-71, held in the Chicago Field Museum of Natural History. Unpublished. Depositary: Library of Carol Inskipp.

Anonymous 1992a. Recently seen! Nepal Bird Watching Club Bulletin $1(3): 2$.

Anonymous 1992b. Recently seen! Nepal Bird Watching Club Bulletin 1(1-2):6.

Anonymous 2019.Additional sighting! Danphe 28(2):11.

Anonymous 2020. Additional sightings! Danphe 29(1):16.

Arora, G., Inskipp, T. P., Baral, H. S., Inskipp, C. and Sharma, P. in prep. Review of Himalayan grasshopper Warbler Locustella kashmirensis, with new wintering records from India and Nepal, and discussion of Himalayan breeding records of Spotted grasshopper Warbler L. thoracica.

Bailey, F. M. 1938. Register of bird specimens collected in Nepal 193538 and presented to the British Museum (Natural History), unpublished.

http://himalaya.socanth.cam.ac.uk/collections/inskipp/1938_001. pdf_Accessed on 5 November 2020.

Baker, T. 1981. Notes on birds recorded in Nepal, 1981. Unpublished.

30 pp. http://himalaya.socanth.cam.ac.uk/collections/inskipp/1981_002.pdf Accessed on 5 November 2020. http://himalaya.socanth.cam.ac.uk/collections/inskipp/1981_007. pdf Accessed on 5 November 2020.

http://himalaya.socanth.cam.ac.uk/collections/inskipp/1981_012. pdf_Accessed on 5 November 2020.

Baker, T. 1983. Notes on birds recorded in Nepal, February - March 1983, unpublished.

http://himalaya.socanth.cam.ac.uk/collections/inskipp/1983_005. pdf Accessed on 5 November 2020.

http://himalaya.socanth.cam.ac.uk/collections/inskipp/1983_006. pdf_Accessed on 5 November 2020.

Baral, H. S. 1989. Notes on birds recorded at Gaida Wildlife Camp, Royal Chitwan National Park, 1988-1989. Unpublished. Depositary: Library of Carol Inskipp.

Baral, H. S. 1991. Birds and mammals recorded in east Nepal. Unpublished. Depositary: Library of Carol Inskipp

Baral, H. S. 1992. Birds from Nepalganj. Unpublished. Depositary: Library of Carol Inskipp.

Baral, H. S. 2005. Birds of Koshi. Bird Conservation Nepal and Department of National Parks and Wildlife Conservation, Kathmandu. 
Baral, H. S. 2011. Birds observed on a trek to Ghunsa, Kanchenjunha Conservation Area. Unpublished. Depositary: Library of Carol Inskipp

Baral, H. S., Giri, T., Choudhary, B. and GC, S. 2003. Moustached Warbler Acrocephalus melanopogon: a new species for Nepal. Danphe 12(1/2):1-2.

Baral, H. S., Tamang, R., Giri, T., Chaudhary, B., Bidari, B., Mahato, B., Chaudhary, F., Chaudhary, R. G., Tamang, S. and Karmacharya, R. 2018. Rediscovery of Red-faced Liocichla Liocichla phoenicea in Nepal and other notable birds from Gadhi, Chitwan, Nepal. Indian BIRDS 14(5):155-157. http://indianbirds.in/pdfs/IB_14_5_BaralETAL_RedfacedLiocichla .pdf Accessed on 5 November 2020.

Baral, H. S. and Upadhyay, G. P. 2006. Birds of Chitwan. Bird Conservation Nepal, Participatory Conservation Programe II Department of National Parks and Wildlife Conservation (UNDP/PCP) and Department of National Parks and Wildlife Conservation, Kathmandu.

Basnet, S. 2008. Report on Rare Birds in Nepal 2008. Danphe 17(4):6-

Basnet, S. and Choudhary, B. 2002. Purple-backed Starling Sturnus sturninus: a new species for Nepal. Forktail 19:129.

Beaman, M. A. S. 1973. Report of the ornithological Cambridge University expedition to the Himalayas, 1973, unpublished. Depositary: Library of Carol Inskipp.

Bhusal, K. P., Rana, D. B., Joshi, A. B., Chaudhary, I. P., Ghimire, P. and Pandey, M. 2020. Diversity and abundance of winter wetland birds in Jagdishpur reservoir Ramsar Site, Kapilvastu, Nepal. Danphe 29(1):1-14.

Biswas, B. 1968. Some new bird records for Nepal. Journal of Bombay Natural History Society 65: 782-784.

Bluefield, A. and Bluefield, J. 2008. Red-necked Phalarope Phalaropus lobatus sighting at Phoksundo Lake, Dolpo. Danphe 17(4):5

Byers, C. and Adams, A. 1983. Notes on birds recorded in Nepal, 1983, unpublished. Depositary: Library of Carol Inskipp,

Byrne, R. W. and Harris, S. M. 1975. Skeletal report of birds and mammals seen during September - November 1975 in Nepal. Unpublished. p 10.

http://himalaya.socanth.cam.ac.uk/collections/inskipp/1975_001. pdf, Accessed on 10 November 2020

Calladine, J. 1985. Nepal and India. Notes on birds and mammals recorded, 18 October - 16 February 1985. Unpublished. 16 pp. http://himalaya.socanth.cam.ac.uk/collections/inskipp/1984_002. pdf Accessed on 7 November 2020

Choudhary, B. 2003. Asian Glossy Starling Aplonis panayensis: a new species for Nepal. Danphe 12(3/4):1.
Choudhary, B. 2004. Asian Glossy Starling Aplonis panayensis: first record for Nepal. Forktail 20:146

Choudhary, H. 1995/1996. Additional sightings! Bird Conservation Nepal Bulletin 4(4)/5(1):2-3.

Choudhary, H. 1996. Additional sightings! Bird Conservation Nepal Bulletin 5(2):2

Choudhary, H. and Inskipp, C. 2017. Bird survey of Annapurna Base Camp trek, Annapurna Conservation Area Danphe 26(1):1-11.

Christensen, S., Bijlsma, R., De Roder, F. and Henriksen, M. 1984. Notes on birds recorded in Nepal, 1984, unpublished. Depositary: Library of Carol Inskipp.

Cocker, M. and Inskipp, C. 1988. A Himalayan ornithologist: The life and work of Brian Houghton Hodgson. Oxford University Press, Oxford.

Cooper, R. 1991. Spotted Crake Porzana porzana: a new species for Nepal. Forktail 6:89-90

Cox Jr., J. 1978. Avian jottings for Nepal, 1978, unpublished; Hall, P. Notes on birds recorded in Nepal, September 1976 - December 1978, unpublished. http://himalaya.socanth.cam.ac.uk/collections/inskipp/1978_001. pdf_Accessed on 10 November 2020.

Curry-Lindahl, K. 1979. Notes on birds recorded in Nepal, 1979 http://himalaya.socanth.cam.ac.uk/collections/inskipp/1979001.p df Accessed on 10 November 2020.

del-Nevo, A. and Ewins, P. 1981. Bird watching in Nepal $7^{\text {th }}$ December 1980 - 19th February 1981. p 14. http://himalaya.socanth.cam.ac.uk/collections/inskipp/1981_006. pdf_Accessed on 10 November 2020.

del-Nevo, A. and Ewins, P. 1983. Rustic Bunting Emberiza rustica - a new species for Nepal. Journal of Bombay Natural History Society 80:417-418.

DeWitt, R. 1982. Notes on birds recorded in Nepal, unpublished.

Dickinson, D. E. 2000. Red Knot Calidris canutus: a new species for Nepal. Danphe 9(1-2):3.

Diesselhorst, G. 1968. Beitrage zur Okologie der Vogel Zentral-und Ost-Nepals. Khumbu Himal 2:1-417.

Dodman, T. and Guinan, Y. 1989. Notes on birds recorded in Nepal, March - April 1989, unpublished. Depositary: Library of Carol Inskipp

Drijvers, R. 1995. India and Nepal, February 1992, December 1993May 1994, January-May 1995. Unpublished birdwatching report. http://himalaya.socanth.cam.ac.uk/collections/inskipp/1992_005. pdf_Accessed on 10 November 2020.

Eames, J. Notes on birds recorded in Nepal, 1982, unpublished. http://himalaya.socanth.cam.ac.uk/collections/inskipp/1982_010 pdf_Accessed on 10 November 2020. 
Eve, V. and Hibberd, G. 1987. Notes on birds recorded in Nepal in 1987, unpublished. Depositary: Library of Carol Inskipp.

Fairbank, R. J. 1980. Notes on birds recorded in Nepal, November 1979 - January 1980, unpublished. Depositary: Library of Carol Inskipp.

Fairbank, R. J. 1982. Notes on birds recorded in Nepal, 1982, unpublished

http://himalaya.socanth.cam.ac.uk/collections/inskipp/1982_012.

pdf_Accessed on 10 November 2020.

Flack, M. 1993. Birds recorded in Nepal in April 1993, unpublished. http://himalaya.socanth.cam.ac.uk/collections/inskipp/1994_003. pdf_Accessed on 10 November 2020.

Fleming, R. L. Jr. in litt. to Carol Inskipp 5 September 1989.

Fleming, R. L. Jr. 1968.The Waxwing Bombycilla garrulus (Linnaeus) in Nepal. Journal of Bombay Natural History Society 65:488.

Fleming, R. L. Sr., Fleming, R. L. Jr. and Bangdel, L. S. 1979. Birds of Nepal Second edition, Avalok, Kathmandu.

Fleming, R. Sr., Fleming, R. L. Jr. and Bangdel, L. S. 1984. Birds of Nepal Third edition, Avalok, Kathmandu.

Fleming, R. L. Sr. and Traylor, M. A. 1961. Notes on Nepal birds Fieldiana: zool. 35(9):447-487. http://ia700202.us.archive.org/13/items/notesonnepalbird358flem/notesonnepalbird358flem.pdf Accessed on 10 November 2020.

Foggitt, G. T. 1999. Long-eared Owl recorded at Pipar, Nepal Unpublished. 1 p. Depositary: Library of Carol Inskipp

GC, S. 2005. Greater White-fronted Goose Anser albifrons: the first record for Nepal. Danphe 14(1/2):1-2.

GC, S. 2018. Himalayan Bush Warbler Locustella kashmirensis, Jagdishpur Reservoir, Kapilvastu district, Nepal, 18 February 2018. Oriental Bird Images http://orientalbirdimages.org/search.php?Bird_ID=2929\&Bird_Image_ID=161060\&Location= nepal Accessed on 8 November 2020.

Gardiner, S. 1990. Notes on birds recorded in Nepal, 1989-1990, unpublished. Depositary: Library of Carol Inskipp.

Gardiner, S. 1991. Mandarin Duck Aix galericulata: a new species for Nepal. Forktail 6:87-88.

Giri. T. and Choudhary, H. 1996. Additional sightings! Bird Conservation Nepal Bulletin 5(3):2.

Giri, T. and Choudhary, H. 1997. Additional sightings! Bird Conservation Nepal Bulletin 6(2):7-8.

Giri, T. and Choudhary, H. 1999. Additional sightings! Danphe 8(2-4):3

Giri, T. and Choudhary, H. 2000a. Additional sightings! Danphe 9(1-2):2.

Giri, T. and Choudhary, H. 2000b. Additional sightings! Danphe 9(3):3

Giri, T. and Choudhary, H. 2001. Additional sightings! Danphe 10(1/2):2.

Giri, T. and Choudhary, H. 2002. Additional sightings! Danphe 11(1):43.

Giri, T. and Choudhary, H. 2003a. Additional sightings! Danphe 12(1/2):3.
Giri, T. and Choudhary, H. 2003b. Additional sightings! Danphe 12(3/4):2-3 Giri, T. and Choudhary, H. 2004a. Additional sightings! Danphe 13(1/2):11. Giri, T. and Choudhary, H. 2004b. Additional sightings! Danphe 13(3/4):4. Giri, T. and Choudhary, H. 2008. Additional sightings! Danphe 17(2):6. Giri, T. and Choudhary, H. 2009. Additional Sightings! Danphe 18(2):9. Giri, T. and Choudhary, H. 2010a. Additional Sightings! Danphe 19(1):3. Giri, T. and Choudhary, H. 2010b. Additional Sightings! Danphe 19(4):11. Giri, T. and Choudhary, H. 2011. Additional Sightings! Danphe 20(2):11. Giri, T. and Choudhary, H. 2012a. Additional sightings! Danphe 21(1):6. Giri, T. and Choudhary, H. 2012b. Additional sightings! Danphe 21(3/4):6. Giri, T. and Choudhary, H. 2016. Additional sightings! Danphe 25: 15. Giri, T. Choudhary, H., Tiwary, S. and Ghimire, S. N. 1999. Additional sightings! Danphe 8(1): 2.

Giri, T., Inskipp, C., Joshi, D., Rawat Y. B. and Poudyal, L. P. in press. First records for six species in Shuklaphanta National Park, western Nepal. Minivet.

Good, J. B. and Ryan, J. 1988. Notes on birds recorded in Nepal 10 February-March 1988, unpublished.

Gooders, J. 1978. A new bird for Nepal and notes on some other scarce species. Journal of Bombay Natural History Society 75(3): 925-926.

Gould, J. 1836. Characters of some new birds in the Society's collection, including two new genera Paradoxornis and Actinodura. Proceedings of Zoological Society of London 4:1719.

Gould, J. 1837-1838. Icones Avium or figures and descriptions of new and interesting species of birds from various parts of the globe, London.

Gray, J.E. and Gray, G. R. 1846. Catalogue of the specimens and drawings of mammals, birds, reptiles and fishes of Nepal and Tibet, presented by B. H. Hodgson, Esq. to the

British Museum. London.

Gray, J. E. 1863. Catalogue of the specimens and drawings of mammals, birds, reptiles and fishes of Nepal and Tibet, presented by B. H. Hodgson Esq to the British Museum. Second edition.

Gregory-Smith, R. C. and Batson, F. 1976. Birds of south-east Nepal. http://himalaya.socanth.cam.ac.uk/collections/inskipp/1976_001. pdf_Accessed on 7 November 2020.

Grimmett, R. F. 1982. Notes on birds recorded in Nepal, 1982, unpublished

http://himalaya.socanth.cam.ac.uk/collections/inskipp/1982_011. pdf_Accessed on 7 November 2020.

Gurung, K. K. Heart of the Jungle. Andre Deutsch, London.

Halberg, K. 1987. Notes on birds recorded in Nepal, November 1985 and April - June 1987, unpublished. 
http://himalaya.socanth.cam.ac.uk/collections/inskipp/1985_006. pdf_Accessed on 7 November 2020.

Halberg, K. and Petersen, I. 1983. Himalaya 1978-1983. Observations of birds, mammals and some reptiles. Unpublished. p 29. http://himalaya.socanth.cam.ac.uk/collections/inskipp/1983_003. pdf_Accessed on 7 November 2020.

Hall, J. 1981. Notes on birds recorded in Nepal, November 1980 March 1981, unpublished. http://himalaya.socanth.cam.ac.uk/collections/inskipp/1981_009.pdf. Accessed on 7 November 2020.

Halliday, J. 1982. A study of the ecological distribution of resident and migratory birds along the Rapti and Narayani rivers in the Roya Chitwan National Park, November - December 1982. Unpublished report to Department of National Parks and Wildlife Conservation, Kathmandu. p 68 . http://himalaya.socanth.cam.ac.uk/collections/inskipp/1983_010.pdf. Accessed on 7 November 2020.

Halliday, J. 1983. Birds recorded in Nepal (excluding Chitwan National Park), 12 October 1982 - 8 January 1983. Unpublished. p 10 http://himalaya.socanth.cam.ac.uk/collections/inskipp/1982_007. pdf_Accessed on 7 November 2020.

Heath, P. J. 1986. Notes on birds recorded in Nepal, 25 January - 4 April 1986, $\quad$ unpublished. $\quad$ p 52 http://himalaya.socanth.cam.ac.uk/collections/inskipp/1986_005. pdf_Accessed on 7 November 2020.

Heinen, J. 1988. Rare and new bird records for Koshi Barrage and Koshi Tappu Wildlife Reserve, Nepal during winter and spring 1987. Journal of Natural History Museum. (Tribhuvan Univ. Kathmandu) 10:23-30.

Himalayan Nature 2020a. National Red List of Birds www.himalayannature.org Accessed on 5 November 2020.

Himalayan Nature 2020b. Bird ringing data from 9 January 2020 to 26 January 2020. 670 birds. Himalayan Nature. Unpublished Depositary: Library of Hem Sagar Baral.

Hodgson, B. H. 1829a. Notes and original watercolour paintings of the birds of Nepal, Tibet and India, held in the Zoological Society of London Library, unpublished. Depositary: Library of Zoological Society of London.

Hodgson, B. H. 1829b. On a new species of Buceros. Gleanings in Science 1:249-252; (1832) Proceedings of Zoological Society of London 2:10-16; (1833) Asiatic Researches 18(2):178-186.

Hodgson, B. H. 1832. On a new species of Buceros. Proceedings of Zoological Society of London 2:10-16.

Hodgson, B. H. 1833a. On the migration of the Natatores and Grallatores, as observed at Kathmandu. Asiatic Researches 18(2):122-128.
Hodgson, B. H. 1833b. On a new species of Buceros. Asiatic Research 18(2):178-186).9

Hodgson, B. H. 1836a. Notices of the ornithology of Nepal. 7. Two new species of the parrot tribe. Asiatic Researches 19:177-178.

Hodgson, B. H. 1836b. Notices of the ornithology of Nepal. 3. New genera of the Columbidae. Asiatic Researches 19:159-164.

Hodgson, B. H. 1836c. Description of two new species belonging to a new form of the Meruline group of birds with indication of their generic character. Journal of Asiatic Society of Bengal 5: 358360.

Hodgson, B. H. 1837a. Indian quails. Bengal Sporting Magazine 9:343346.

Hodgson, B. H. 1837b. On some new genera of Raptores, with remarks on the old genera. Journal of Asiatic Society of Bengal 6:361373.

Hodgson, B. 1839. On a new genus of the Fissirostral tribe. Journal of Asiatic Society of Bengal 8:35-36.

Hodgson, B. H. 1844. Catalogue of Nipalese birds, collected between 1824 and 1844. In Gray, J. E. Zoological Miscellany, June 1844. Hodgson, B. H. 1845. On Nepalese birds. Proceedings of Zoological Society of London 13:22-37.

Holt, P., Crossley, R. and Moores, C. 1986. Notes on birds recorded in Nepal, January - April 1986, unpublished. Depositary: Library of Carol Inskipp.

Hurrell A. G. 1988. Notes on birds recorded in Nepal 1984-88, unpublished. Depositary: Library of Carol Inskipp.

Inskipp, C. 2004. Report on rare birds in Nepal 2003. Danphe 13(1/2):1-4.

Inskipp, C. 2005. Report on rare birds in Nepal in 2004. Danphe 14(1/2):4-5.

Inskipp, C. 2006. Report on rare birds in Nepal 2005. Danphe 15(1):45.

Inskipp, C. 2020. A lowland Nepal trip in February and March 2020. Himalayan Nature blogpost. https://www.himalayannature.org/blog/3/nepal-trip-march-2020 Accessed on 10 November 2020.

Inskipp, C., Baral, H. S., Phuyal, S., Bhatt, T. R., Khatiwada, M., Inskipp, T., et al. 2016.The status of Nepal's Birds: the National Red List Series. Zoological Society of London. http://www.himalayannature.org Accessed on 7 November 2020. Inskipp, C. and Chaudhary, H. 2016. The first record of West Himalayan Bush Warbler Locustella kashmirensis for Nepal. Indian BIRDS 12(4\&5):138-139. http://indianbirds.in/pdfs/IB_12_4_5_Inskipp_Chaudhary_WestHi malayanBushWarbler.pdf Accessed on 7 November 2020. 
Inskipp, C., Giri, T. R., Joshi, D. R., Poudyal, L. P. and Rawat, Y. 2020. Notable bird records, Shuklaphanta National Park 9-12 March 2020, unpublished. Depositary: Library of Carol Inskipp.

Inskipp, C. and Inskipp, T. P. 1982. Notes on birds recorded in Nepal April-June 1982, unpublished. http://himalaya.socanth.cam.ac.uk/collections/inskipp/1982_015.pdf. Accessed on 7 November 2020.

Inskipp, T. P.1971. Notes on birds recorded in Nepal, September 1970 - March 1971, unpublished. Depositary: Library of Carol Inskipp. Inskipp, T. P. 2012. Bibliography of birds of Nepal. Unpublished. Depositary: Libraries of Tim Inskipp and Carol Inskipp.

Inskipp, T. P. and Inskipp, C. 1981. Notes on birds recorded in Nepal February - March 1981, unpublished.

http://himalaya.socanth.cam.ac.uk/collections/inskipp/1981_013. pdf_Accessed on 8 November 2020.

Jayapal, P., Inskipp, T. and Thompson, P. M. 2017. Letter to the Editor. Radde's Warbler Phylloscopus schwarzi from the Indian Subcontinent-withdrawal of records. Indian BIRDS 15(3): 96A http://indianbirds.in/pdfs/IB_15_3_PraveenETAL_LetterToEditor. pdf Accessed on 8 November 2020.

Joshi, D. 2018. Bird notes of Shuklaphanta, 2018. Unpublished. Depositary: Library of Devraj Joshi.

Juliusberger, R. 1987. A birdwatching tour to India and Nepal, 30 November 1986 - 16 April 1987, unpublished. Depositary: Library of Carol Inskipp.

Justice, S. 1978. Notes on birds recorded in Nepal, 1976-78 unpublished. Depositary: Library of Carol Inskipp.

Kennerley, P. and Karki, R. 2004. Trip report: foothills of the Himalayas. $29^{\text {th }}$ February - 14th March 2004. Unpublished. Depositary: Library of Carol Inskipp

Kennerley, P. and Turnbull, M. 1989. Report on a birding trip to Nepal, 4-20 February, unpublished.

http://himalaya.socanth.cam.ac.uk/collections/inskipp/1989_018. pdf Accessed on 8 November 2020.

http://himalaya.socanth.cam.ac.uk/collections/inskipp/1989_021. pdf Accessed on 8 November 2020.

http://himalaya.socanth.cam.ac.uk/collections/inskipp/1989_022. pdf_Accessed on 8 November 2020.

Krabbe, E. 1983. List of bird specimens in the Zoological Museum of Copenhagen, collected by G. B. Gurung, S. Rana and P. W Soman from Nepal, 1959. Unpublished. 19 pp. http://himalaya.socanth.cam.ac.uk/collections/inskipp/1983_008. pdf_Accessed on 8 November 2020.

Krabbe, N. 1981. India and Nepal, 1981, ornithological report. Unpublished. Accessed on 8 November 2020.
Kusi, N., Lama, T. L., Lama, P. R. and Werhahn, G. 2017. The first record of Rufous-tailed Rock-Thrush Monticola saxatilis in Nepal. Birding ASIA 27:116-117.

Lama, S. 1992. Recently seen! Nepal Bird Watching Club Bulletin 2(2):2.

Lama, S. 1993a. Recently seen! Nepal Bird Watching Club Bulletin 2(4):3.

Lama, S. 1993b. Recently seen! Nepal Bird Watching Club Bulletin 2(3):2.

Lama, S. 1993c. Recently seen! Nepal Bird Watching Club Bulletin 2(1):2-3.

Lama, S. 1994a. Additional sightings! Nepal Bird Watching Club Bulletin 3(3):5.

Lama, S. 1994b. Additional sightings! Nepal Bird Watching Club Bulletin 3(2):2-3.

Lama, S. 1994c. Additional sightings! Nepal Bird Watching Club Bulletin 3(1):3-4

Lama, S. 1995. Additional sightings! Bird Conservation Nepal Bulletin 4(3):2.

Lambert, F. L. 1979. Notes on birds recorded in Nepal, 1978-79, unpublished. Depositary: Library of Carol Inskipp.

Lelliott, A. D. 1981. Notes on birds recorded in Nepal, 1978-81, unpublished. Depositary: Library of Carol Inskipp.

Lewis, A. 1994. Asian Stubtail Urosphena squameiceps: a new species for Nepal and the Indian subcontinent. Forktail 9:155.

Linderstrom, S. A. 1989. Notes on birds recorded in India and Nepal, 28 January - 27 February 1989. Unpublished. Depositary: Library of Carol Inskipp.

Madge, S. C., Dukes, P. A., Westwood, C. W. and Robinson, M. C. 1974. Notes on birds recorded in Nepal, December 1973 February 1974. Unpublished. p 47. http://himalaya.socanth.cam.ac.uk/collections/inskipp/1974_003. pdf_Accessed on 9 November 2020.

Madge, S. C. and Redman, N. 1986. Selected notes on Bird quest Nepal tour, February - March 1986. Unpublished. p 4. http://himalaya.socanth.cam.ac.uk/collections/inskipp/1986_006. pdf_Accessed on 9 November 2020.

Martens, J. and Eck, S. 1995. Towards an ornithology of the Himalayas: systematics, ecology and vocalizations of Nepal birds. Bonner Zoologische Monographien Nr 38. Bonn, Germany: Zoologisches Forschungsinstitut und Museum Alexander Koenig.

Mills, D. G. H. and Preston N. A. 1981. Notes on birds recorded in Nepal, 1981, unpublished. Depositary: Library of Carol Inskipp.

Mills, D. G. H., Preston, N. A. and Winyard, C. 1982. Notes on birds recorded in Nepal 1982, unpublished. Depositary: Library of Carol Inskipp. 
Munthe, K. 1981. Notes on birds recorded in Nepal, December 1980 January 1981. Unpublished. p 6. http://himalaya.socanth.cam.ac.uk/collections/inskipp/1981_011.pdf__Accessed on 10 November 2020.

Nepali, H. S. 1982. List of Nepalese bird specimens and notes on birds seen in Nepal, unpublished. Depositary: Library of Carol Inskipp.

Nickel, H. and Trost, R. 1983 Vogelkundliche beobachtungen einer reise nach Indien und Nepal, January - April 1983, unpublished. Depositary: Library of Carol Inskipp.

Nicolle, S. 1987. Notes on birds recorded in Nepal, 1987. Unpublished. Depositary: Library of Carol Inskipp,

Nielsen, J. T. and Jakobsen, O. F. 1989. Notes on birds recorded in Nepal, 25 October - 23 November 1989. Unpublished. Depositary: Library of Carol Inskipp.

Parr, M. 1982, Notes on birds recorded in Nepal, 1982, unpublished. Depositary: Library of Carol Inskipp.

Porter, R. F., Oddie, W. E. and Marr, B. A. E. 1981. Notes on birds recorded in Nepal, February 1981, unpublished. Depositary: Library of Carol Inskipp.

Poudyal, L. P. and Chaudhary, H. 2019. Birds of Shuklaphanta National Park. Shuklaphanta National Park Office and Nepalese Ornithological Union, Kanchanpur and Kathmandu.

Prince, M. 1998. Naturetrek tour, 13-22 February 1998. Unpublished. Depositary: Library of Carol Inskipp.

Pritchard, D. E. and Brearey, D. 1983. Notes on birds recorded during the Saipal 1982/83 expedition to Nepal, unpublished. Depositary: Library of Carol Inskipp,

Pyle, P. 1982. Notes on birds recorded in Nepal, 1982, unpublished.

Rand, A. L. and Fleming, R. L. 1957. Birds of Nepal. Fieldiana: zoologica 41:1-218. http://www.biodiversitylibrary.org/item/24863\#page/8/mode/1up Accessed on 10 November 2020.

Redman, N. 1993. Langtang, Gosainkund and Helambu, 7-30 May 1993. Birdquest tour. Unpublished. p 64. http://himalaya.socanth.cam.ac.uk/collections/inskipp/1993_010. pdf_Accessed on 11 November 2020.

Redman, N. J., Lambert, F. and Grimmett, R. F. 1984. Some observations of scarce birds in Nepal. Journal of Bombay Natural History Society 81:49-53.

Redman, N. J. and Murphy, C. 1979. Notes on birds recorded in Nepal, December 1978-June 1979, unpublished. Depositary: Library of Carol Inskipp.

Roberts, R. 1985. Notes on birds recorded in Nepal 1985, unpublished. Depositary: Library of Carol Inskipp.

Robson, C.1982. A report of birds seen in Nepal, 1982, unpublished. http://himalaya.socanth.cam.ac.uk/collections/inskipp/1982_003. pdf_Accessed on 10 November 2020
Ross, J. 1983. Notes on birds recorded in Nepal, January - April 1983, unpublished

http://himalaya.socanth.cam.ac.uk/collections/inskipp/1983_004. pdf_Accessed on 10 November 2020.

Round, P. and Baral, H. S. 2013. A record of David's Bush Warbler Bradypterus davidi in Nepal. BirdingAsia 20:107-109. https://www.researchgate.net/publication/277813191_A_record of_David\%27s_Bush_Warbler_Bradypterus_davidi_in_Nepal Accessed on 24 November 2020.

Sharpe, R. B. 1883. Catalogue of the birds in the collection of the British Museum, 7-Timaliidae (part). London: British Museum.

Sharpe, R. B. 1894. Catalogue of the birds in the collection of the British Museum, Volume 23 - Fulicariae, Alectorides. London, UK: British Museum

http://www.biodiversitylibrary.org/bibliography/8233_Accessed on 24 November 2020

Shrestha, A. 2017. Photograph of Moustached Warbler Acrocephalus melanopogon at Jagdishpur Reservoir, 3 February 2017. https://mybirdsofnepal.com/2017/05/24/moustached-warbler/ Accessed on 24 November 2020.

Sieurin, P. 1987. Record of Bean Goose Anser fabalis in Nepal, unpublished. Depositary: Library of Carol Inskipp.

Slack, R. S. 1990. Notes on birds recorded in Nepal, December 1989 - February 1990, unpublished. Depositary: Library of Carol Inskipp.

Stones, A. J. 1987. Bird species recorded in Nepal, 8 March - 5 April 1987. Unpublished. P 10. http://himalaya.socanth.cam.ac.uk/collections/inskipp/1987_009. pdf_Accessed on 12 November 2020.

Subedi T. and DeCandido R. 2013. Indian vulture (Gyps indicus): a new bird species for Nepal. BirdingASIA 19:115-116.

Suter, W. 1983. Ornithological and mammalogical observations in Nepal and NW India, including a few observations in Bangladesh and Pakistan. Unpublished. Depositary: Library of Carol Inskipp.

Tebb, G., Arlow, S. and Giri, D. 2004. First record of Red-throated Diver Gavia stellata for Nepal. Forktail 20:107-109.

Tebb, G., Ofner, A. and Basnet, S. 2002. Red-headed Bunting Emberiza bruniceps: from Koshi Tappu Wildlife Reserve Danphe 11(2):3-4.

Tebb, G., Ofner, A. and Basnet, S. 2004. First documented record of Red-headed Bunting Emberiza bruniceps from Nepal. Forktail 20:99-100.

Thiollay, J. M., 1977. Notes on birds recorded in Nepal. Unpublished. Depositary: Library of Carol Inskipp.

Thiollay, J. M. 1980. L'evolution des peuplements d'oiseaux le long d'un gradient altitudinal dans l'Himalaya Central. Revied Ecology (Terre et Vie) 34:99-269. 
Tolk, R. 1988. Notes on birds recorded in Nepal, 1984, unpublished.

Turin, R., Heegaard, M. and Prieme, A. 1987. Northern part of the Indian subcontinent 87. Unpublished. p 27.

http://himalaya.socanth.cam.ac.uk/collections/inskipp/1987_010. pdf_Accessed on 12 November 2020.

Turton, M. and Speight, G. 1982. A report on birds seen in Nepal, 1982, unpublished. http://himalaya.socanth.cam.ac.uk/collections/inskipp/1982_008. pdf_Accessed on 12 November 2020.

Vyas, S. 1988. Notes on birds recorded in Nepal, 1986-1988. http://himalaya.socanth.cam.ac.uk/collections/inskipp/1988_018. pdf_Accessed on 12 November 2020.

Walinder, G. and Sandgren, B. 1983. Artlista over faglar observerade i Nepal, 10.3 - 12.4 1982. http://himalaya.socanth.cam.ac.uk/collections/inskipp/1982_014.pdf. Accessed on 12 November 2020.

Warren, R. L. M. and Harrison, C. J. O. 1971. Type specimens of birds in the British Museum (Natural History) 1, Non-Passerines. British Museum (Natural History), London.

Whitehouse, S. 1982. Notes on birds recorded in Nepal, 1982, unpublished. Depositary: Library of Carol Inskipp.

\section{Cite this article as:}

Inskipp, C., Baral, H. S., Acharya, S., Chaudhary H., Ghimire, M. and Giri, D. 2020. Rare birds in Nepal. Nepalese Journal of Zoology 4(2):108-132. https://doi.org/10.3126/njz.v4i2.33894 